\title{
Research Profiling for Responsible and Sustainable Innovations
}

\author{
Agata Sudolska ${ }^{1, *(\mathbb{C})}$, Andrzej Lis ${ }^{2} \mathbb{( 1 )}$ and Monika Chodorek ${ }^{3}$ \\ 1 Department of Enterprise Management, Faculty of Economic Sciences and Management, \\ Nicolaus Copernicus University, Gagarina 13a, 87-100 Torun, Poland \\ 2 Department of Business Excellence, Faculty of Economic Sciences and Management, Nicolaus Copernicus \\ University, Gagarina 13a, 87-100 Torun, Poland; andrzejlis@econ.umk.pl \\ 3 WSB University in Torun, Institute of Management, Mlodziezowa 31a, 87-100 Torun, Poland; \\ monika.chodorek@wsb.torun.pl \\ * Correspondence: aga@econ.umk.pl; Tel.: +48-56-6114890
}

Received: 27 October 2019; Accepted: 18 November 2019; Published: 20 November 2019

\begin{abstract}
The issues of responsible and sustainable innovations have been attracting the growing attention of the ranks of scholars in recent years. However, this amassing productivity in the field has not been mapped and profiled thoroughly, yet. Therefore, the aim of the paper is to map the research output related to the concepts of responsible and sustainable innovations with the method of research profiling. The analysis consists of three components: general research profiling, subject area profiling and topic profiling conducted with the use of Scopus database. The research process is directed at answering three research questions: (1) who are the main contributors within the scholarly community? why? so what? (2) how is the research output distributed among subject areas? why? so what? (3) what are the central topics and issues discussed within the research field? why? so what? First of all, key contributing countries, research institutions, journals, and authors are identified in order to characterize the scholarly community working in the field. Secondly, research output is profiled through the prism of respective subject areas. This type of profiling aims at discovering varieties among key journals, authors and core references distributed across various subject areas. Thirdly, topic analysis is conducted in order to point out most crucial aspects studied in the body of literature in the field. The research sample consists of 1083 publications indexed in Scopus database, including the phrases 'responsible innovation' or 'sustainable innovation' within their titles, keywords, and abstracts (topic search). The findings from the general research profiling confirm the growing interest of academia in exploring and investigating the issues of responsible and sustainable innovations. The leading contributors in the field are scholars and research institutions from the Netherlands, the United Kingdom, and the United States. Dutch universities and research centers occupy three top three positions in regard to the number of publications. Among them, Delft University of Technology is the unquestionable leader. Journal of Cleaner Production and Journal of Responsible Innovation are found to be the most prolific and highly recognized source titles in the field. Subject area profiling shows a relatively high level of interrelatedness among the four leading subject areas i.e., Business, Management and Accounting, Engineering, Social Sciences, and Environmental Science in regard to authors, source titles and core references. Topic profiling indicates two leading thematic streams in the research field focused on the features and core aspects of responsible and sustainable innovations, and the relationships of the concept with people (human, humans), research, ethics, and technology. Discussion of research findings is focused around comparing and contrasting three overlapping concepts (i.e., responsible research and innovation, responsible innovation, and sustainable innovation), providing the critical assessment of the reasons for the scholarly research to have developed along with certain patterns and identifying unexplored aspects or possible future avenues of research.
\end{abstract}


Keywords: responsible innovation; sustainable innovation; bibliometrics; research profiling

\section{Introduction}

The discussion on the responsibility of business for the impact on society as well as the environment has matured over the last few decades, resulting in comprehensive literature across several fields of study [1-7]. Among others, the issue of business responsibility involves the problems of broadly understood innovations. Recently, in the above-said literature stream, responsible innovation has emerged as a new approach that expands on previously proposed concepts related to business responsibility by drawing on technology assessment, ethics in science and technology studies, and ethical, legal, as well as social aspects at the start of innovation process [8-13]. The main idea of the concept is to democratize innovation as well as realize deliberative forms of governance through stakeholder and public engagement [14-16]. Although generally innovation is perceived as inherently good, there is always a probability that it may have some unforeseen consequences. Today, there is a considerable agreement among researchers on the fact that even the most promising innovation can fail due to ethical and societal concerns that result from the innovation but were not properly taken into account $[14,17,18]$. Also, the way people think today about responsibility, from the perspective of innovations, is changing by reflecting the modern context in which innovations occur $[15,19,20]$. In consequence, nowadays, the scope of responsibility in regard to innovations goes beyond legal requirements and business standards and encompasses the expectations of stakeholders and values related to the society and the natural environment required at the markets, where innovations are planned to be implemented. In such a context, the literature introduces the ideas of responsible and sustainable innovations $[9,15,21]$.

The importance of responsible and sustainable innovations refers to the fact that these ideas are considered as up-to-date holistic and multidisciplinary concepts highlighting the problem of dynamic capability used to develop a long-term firm sustainable advantage. Focus on responsible and sustainable innovations forces companies to learn new approaches and let go of old ones around the search for innovation $[15,21]$. It entails governing through early 'upstream' interventions rather than 'downstream' monitoring and 'correction' of interventions ex-post. The discussion on responsible and sustainable innovations is momentous as frequently one can observe significant time lags between the development of innovations, understanding of their wider impacts as well as subsequent governance. Therefore, nowadays there is an urgent need for more anticipatory and adaptive approaches that help to understand the ways in which new technologies and social practices enable societies to become more sustainable and that help unleash a new era of economic development [15].

The issues of responsible and sustainable innovations have been attracting the growing attention of the ranks of scholars in recent years. However, this growing research output in the field has not been mapped and profiled thoroughly, yet. The search in Scopus and Web of Science databases, conducted on 27 May 2018, shows no records for the conjunction of phrases 'responsible innovation' OR 'sustainable innovation' AND 'research profiling' in titles, keywords and abstracts of indexed publications. Such an observation reveals the gap in the research field. It allows to state that the assessment of the research productivity in a quantitative and systematic way is not found in the literature. Thus, there is a need for a research profiling analysis that studies 'responsible innovation' as well as 'sustainable innovation' from a global perspective. Filling the identified research gap is a motivation for undertaking the research. Traditional literature surveys, regardless of whether they are of simple narrative or even systematic character, are flawed with incompleteness resulting from the limited number of publications included for qualitative analysis. Employing the method of research profiling gives the opportunity to conduct the quantitative analysis of a wide body of literature in order to identify research trends and patterns. Combining this quantitative approach with the qualitative systematic review used to support discussion and interpretation of collected data ensures the triangulation of research methodology and 
increases quality assurance of the study. As mentioned above, so far there has not been such a research profiling study in the field. Therefore, using this particular bibliometric method to map the research field is something that makes this study exceptional and differentiates it from other surveys in the field. It contributes to the novelty of the study and its potential to become an important publication in light of all other existing and recent reviews in the field.

Taking into account the identified gap in the body of knowledge and the aforementioned motivations, the aim of the paper is to map the research output related to the concepts of responsible and sustainable innovations. The research process is focused on the following research questions: (1) who are the main contributors (countries, affiliated institutions, source titles, authors) within the scholarly community? why? so what? (2) how is the research output distributed among subject areas? why? so what? (3) what are the central topics and issues discussed within the research field? why? so what?

\section{Method and Structure of Study}

The method of research profiling is applied to achieve the aforementioned aim and provide answers to research questions. Research profiling is categorized among the methods of bibliometric descriptive studies aimed at exploring the features of the body of knowledge in the given research field [22] (pp. 150-151). The research profiling method shows a high potential to augment traditional literature reviews by exploring a wide range of literature in order to identify patterns and research trends [23] (pp. 351-353). Therefore, research profiling may be considered as an effective tool used to map the research field.

The work by Martinez et al. [24] was used as a benchmark to design the research process and structure the paper. Moreover, some other publications applying research profiling methodology provided inspirations and guidelines [25-27]. The structure of the paper follows the pattern of the research profiling methodology and consists of three components i.e., general research profiling, subject area profiling, and topic profiling. First of all, key contributing countries, research institutions, journals, and authors are identified in order to characterize the scholarly community working in the field. Secondly, research output is profiled through the prism of respective subject areas. This type of profiling aims at discovering varieties among key journals, authors and core references distributed across various subject areas. Thirdly, topic analysis is conducted in order to point out the most crucial aspects studied in the body of literature in the field. Results presentation and analysis is concluded with the discussion section aimed at interpreting the findings in the context of the existing literature in the field. The method of a systematic literature review is used to support discussion and interpretation of the findings.

\section{Research Sample}

Within the field of study, the variety of concepts combining the ideas of innovations and corporate social responsibility may be observed. For instance, Lis and Sudolska [28] identify twelve of such concepts including: responsible innovations (RI), responsible research and innovations (RRI), socially responsible innovations (SRI), social innovation (SocI), sustainable innovations (SI), environment innovations (EI), eco-innovations (EcoI), green innovations (GI), inclusive innovations (II), frugal innovations (FI), grassroots innovation (GRI), and workplace innovations (WI). The aforementioned concepts vary in scope, some of them refer in general to the ideas of responsibility or sustainability, the others focus on particular aspects such as the environment, society or employees. Some of these concepts are stand-alone, while others overlap. Being aware of complexity and multidimensionality of the concepts in the research field, we decided to focus the mapping process on responsible innovations and sustainable innovations, which both are comprehensive categories, their definitions are close to each other and their scopes encompass other concepts mentioned above. It should be made explicit that such a solution has both advantages and limitations. On the one hand, 
it increases the consistency of the research sample, while on the other hand reduces the number of items included in the sample.

The process of research sampling was conducted with the use of the Scopus database. As of 27 May 2018, the pair of phrases 'responsible innovation' OR 'sustainable innovation' was searched within titles, keywords, and abstracts of publications indexed in Scopus. In total, 1083 records were retrieved, which were used for research profiling. The majority of the research sample is made up of articles $(593,54.76 \%)$, conference papers $(199,18.37 \%)$, and book chapters $(104,9.60 \%)$. All the categories of publications included in the sample are listed in Table 1.

Table 1. The structure of the research sample by document type.

\begin{tabular}{ccc}
\hline Document Type & $\mathbf{N}$ & $\mathbf{\%}$ \\
\hline Article & 593 & 54.76 \\
Conference paper & 199 & 18.37 \\
Book chapter & 104 & 9.60 \\
Review & 66 & 6.09 \\
Editorial & 31 & 2.86 \\
Article in press & 25 & 2.31 \\
Book & 24 & 2.22 \\
Conference review & 11 & 1.02 \\
Note & 11 & 1.02 \\
Short survey & 11 & 1.02 \\
Letter & 5 & 0.46 \\
Erratum & 3 & 0.28 \\
\hline
\end{tabular}

Source: Own study based on data retrieved from the Scopus database (accessed 27 May 2018).

The value of the $h$-index for the research profiling sample is 44. Identification of the most prominent works within the field was used as the foundation for building up the corpus of publications used for systematic literature review supporting discussion and interpretation of the research profiling findings. Then, using abstract analysis, the papers most relevant to the topic and aim of the study were chosen. The advantage of such an approach is to ensure that all the relevant and, simultaneously, the most influential (i.e., those receiving the highest number of citations) publications in the field are included. Nevertheless, this procedure of sampling has some weaknesses as well. For instance, there is a risk of neglecting some key and important papers published recently which so far have not been cited so much (which is quite likely) or papers not including searched keywords ('responsible innovation' or 'sustainable innovation') in their titles, keywords, and abstracts (less likely). Moreover, the Scopus database is biased towards English language publications, which results in the underrepresentation of literature in other languages in the sample. Therefore, using the method of snowball sampling, the body of publications was supplemented with some other works not listed among core references in the research profiling sample.

\section{General Publication Profiling}

\subsection{Number of Publications and Received Citations}

The earliest publication included in the research sample is dated as of 1978. Nevertheless, the main bulk of research output is very recent. The most dynamic growth of researchers' interest in the field has been observed since 2013. The publications making up the research sample have received in total 10,789 citations. Similarly to the number of publications, a significant increase in the number of received citations has been noted in very recent years. Yearly distribution of publications within the sample and citations they received are illustrated in Figure 1. 

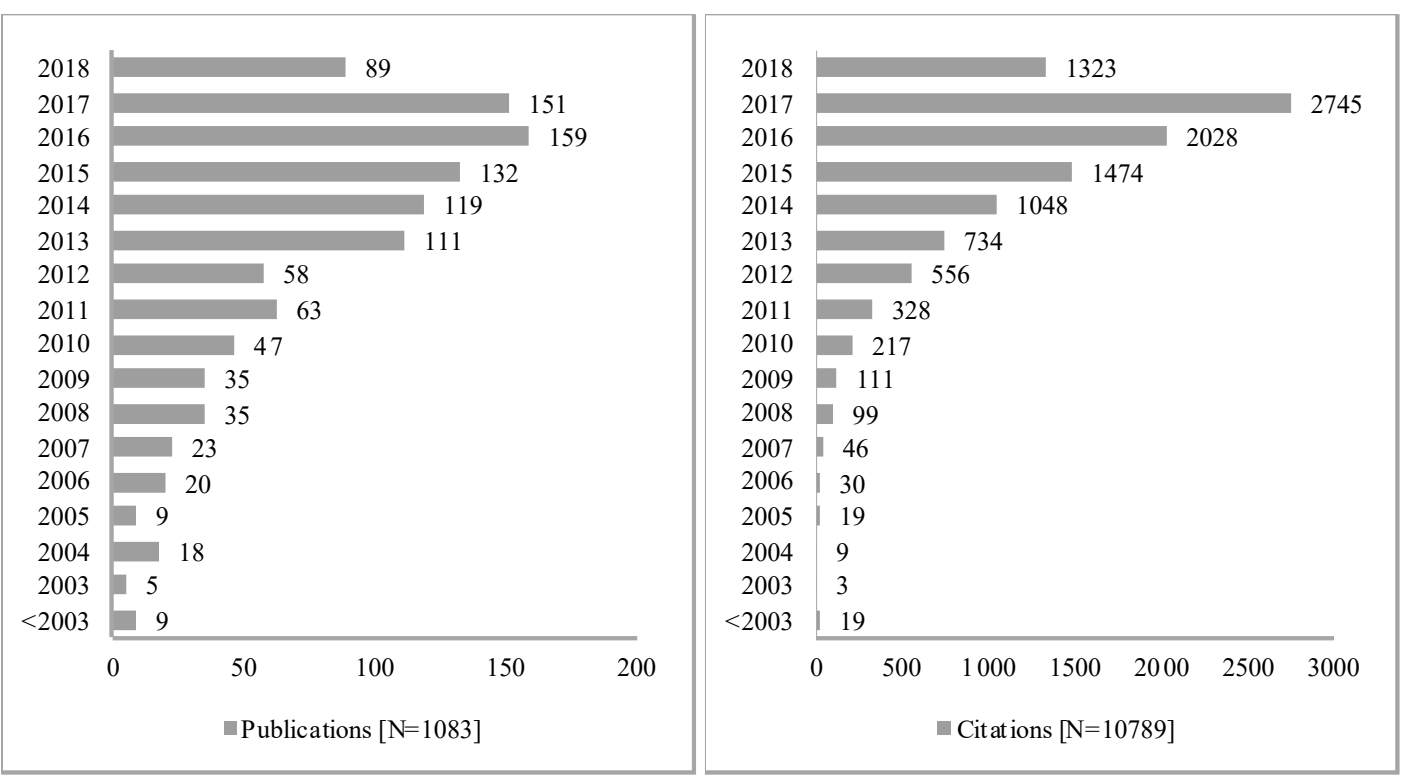

Figure 1. Scientific productivity of research on responsible and sustainable innovations. Source: Own study based on data retrieved from Scopus database (accessed 27 May 2018).

The changes in the scientific productivity (the number of publications) from 2003 to 2017 are best represented with the 2 degree polynomial function $\left(y=0.7404 x^{2}-2964.9 x+3 E+06, R^{2}=0.9647\right)$ or the exponential function $\left(y=5 E-198 e^{0.2279 x}, R^{2}=0.9308\right)$. Similarly, the line of trend for the number of citations received by the publications included in the sample shows characteristics typical of the exponential function $\left(y=0 e^{0.4609 x}, R^{2}=0.9781\right)$ or the 2 degree polynomial function $\left(y=23.342 x^{2}\right.$ $\left.-93670 x+9 E+07, R^{2}=0.9758\right)$. The analysis of research productivity in the field manifested in the number of publications and the number of citations received by these works shows the growing interest of the academia in issues related to responsible and sustainable innovation. Prior to 2003, only single publications are noticed. Then, there is observed a period of slowly growing attention (2003-2012). Recently (2013-2018), the acceleration of the rising trend is reported.

\subsection{Country Profiling}

The research sample includes 84 items of undefined country/territory. The remaining publications are distributed among 55 countries representing all the continents. Table 2 shows the geographical distribution of research in the area of responsible and sustainable innovations.

Table 2. Geographical distribution of research on responsible and sustainable innovations.

\begin{tabular}{|c|c|c|c|c|c|c|c|c|}
\hline \multirow[b]{2}{*}{ No. } & \multirow[b]{2}{*}{ Region } & \multicolumn{3}{|c|}{ Publications } & \multicolumn{4}{|c|}{ Citations } \\
\hline & & $\mathbf{N}$ & $\begin{array}{c}\%[1083= \\
100 \%]\end{array}$ & $\begin{array}{c}\%[1430= \\
100 \%]\end{array}$ & $\mathbf{N}$ & $\begin{array}{c}\%[10,789= \\
100 \%]\end{array}$ & $\begin{array}{c}\%[15,558= \\
100 \%]\end{array}$ & h \\
\hline 1 & Europe & 714 & 65.93 & 49.93 & 9063 & 84.00 & 58.25 & 41 \\
\hline 2 & North America & 232 & 21.42 & 16.22 & 2314 & 21.45 & 14.87 & 22 \\
\hline 3 & Asia & 173 & 15.97 & 12.10 & 1086 & 10.07 & 6.98 & 17 \\
\hline 4 & South America & 96 & 8.86 & 6.71 & 1432 & 13.27 & 9.20 & 15 \\
\hline 5 & Australia and Oceania & 79 & 7.29 & 5.52 & 746 & 6.91 & 4.79 & 14 \\
\hline 6 & Africa & 52 & 4.80 & 3.64 & 592 & 5.49 & 3.81 & 12 \\
\hline \multirow[t]{2}{*}{7} & Undefined territory & 84 & 7.76 & 5.87 & 325 & 3.01 & 2.09 & 6 \\
\hline & Total & 1430 & 132.04 & 100.0 & 15,558 & 144.2 & 100.0 & \\
\hline
\end{tabular}

Source: Own study based on data retrieved from the Scopus database (accessed 27 May 2018).

The leading position of European countries is noticeable in the published papers regarding responsible and sustainable innovation. They account for contributing to over $65 \%$ of all articles in the 
research sample (nearly $50 \%$ if contributions counted separately for each country), and their citation rate falls at $84 \%$ (respectively $58 \%$ ). North America is in the second position and Asia in the third one. A significant difference between Europe and other continents in the number of published articles and received citations should be noticed.

Country profiling can be a reflection of the activity and the academic level in the analyzed field. Table 3 shows the most productive countries in research on responsible and sustainable innovations.

Table 3. Topmost productive countries/territories in research on responsible and sustainable innovations.

\begin{tabular}{ccccccc}
\hline \multirow{2}{*}{ No. } & Country/Territory & \multicolumn{2}{c}{ Publications } & \multicolumn{3}{c}{ Citations } \\
\cline { 3 - 6 } & & $\mathbf{N}$ & $\mathbf{\%}$ & $\mathbf{N}$ & $\mathbf{\%}$ & $\mathbf{h}$ \\
\hline 1. & Netherlands & 219 & 20.22 & 3770 & 34.94 & 27 \\
2. & United Kingdom & 173 & 15.97 & 3823 & 35.43 & 29 \\
3. & United States & 168 & 15.51 & 1729 & 16.03 & 20 \\
4. & Germany & 75 & 6.93 & 1632 & 15.13 & 14 \\
5. & Italy & 59 & 5.45 & 323 & 2.99 & 11 \\
6. & France & 54 & 4.99 & 306 & 2.84 & 10 \\
7. & China & 51 & 4.71 & 176 & 1.63 & 7 \\
8. & Brazil & 47 & 4.34 & 883 & 8.18 & 10 \\
$9-10$. & Denmark & 39 & 3.60 & 508 & 4.71 & 11 \\
$9-10$. & Spain & 39 & 3.60 & 525 & 4.87 & 10 \\
\hline
\end{tabular}

Source: Own study based on data retrieved from the Scopus database (accessed 27 May 2018).

Top 10 most productive countries contribute with $85.32 \%$ of all research output in the field. The group of the most productive countries is made up of representatives of European, North American, South American, and Asian nations. The regions highly concentrated on the research in the field in Europe are the Netherlands and the United Kingdom (together 392 articles). What is also of paramount importance, the research affiliated at institutions in these two countries shows high quality, which is manifested in a high number of received citations and the value of h-index. Other European countries ranked among the top 10, i.e., Germany, Italy, France, Denmark, and Spain, contributed in total with 266 articles. The group of the most productive countries is complemented by the representatives of North America (the United States, $N=168$ articles, rank 3), Asia (China, $N=51$, rank 7), and South America (Brazil, $\mathrm{N}=47$, rank 8). The key contributors from other continents are Australia $(\mathrm{N}=31$, rank 13) and South Africa ( $N=11$, rank 22). Summing up, in regard to quantity of the research output, the leaders in the field are the Netherlands, the United Kingdom, and the United States. Taking into account the quality of the research, Germany should be added to the aforementioned countries.

\subsection{Institution Profiling}

As regards affiliated institutions, there are identified 17 universities that contributed with 10 or more papers. Top 10 most productive universities provided 228 publications ( 268 if calculated separately), which received 4941 citations. The h-index for the top 10 institutions is 41 . They are listed in Table 4.

The most productive institutions in the field come mainly from Europe (seven of them from the Netherlands, two from the United Kingdom) and only one from the United States. The leader is the Delft University of Technology (67 articles). The second position is occupied by Wageningen University and Research Center ( 36 articles) and the third position by Utrecht University (26 articles). As regards the number of received citations, manifesting the quality of research work, the leaders are two universities from the United Kingdom, i.e., the University of Sussex and the University of Exeter. Among the most productive institutions, there are no representatives of other nations found to be leaders in research on responsible and sustainable innovations such as Germany, Italy, France, China, Brazil, Denmark, or Spain. 
Table 4. Topmost productive institutions in research on responsible and sustainable innovations.

\begin{tabular}{|c|c|c|c|c|c|c|c|}
\hline \multirow{2}{*}{ No. } & \multirow{2}{*}{ Institution } & \multirow{2}{*}{ Country } & \multicolumn{2}{|c|}{ Publications } & \multicolumn{3}{|c|}{ Citations } \\
\hline & & & $\mathbf{N}$ & $\%$ & $\mathbf{N}$ & $\%$ & h \\
\hline 1. & Delft University of Technology & Netherlands & 67 & 6.19 & 718 & 6.65 & 13 \\
\hline 2. & $\begin{array}{c}\text { Wageningen University and } \\
\text { Research Center }\end{array}$ & Netherlands & 36 & 3.32 & 242 & 2.24 & 8 \\
\hline 3. & Utrecht University & Netherlands & 26 & 2.40 & 497 & 4.61 & 11 \\
\hline 4. & Arizona State University & United States & 25 & 2.31 & 421 & 3.90 & 8 \\
\hline 5. & University of Twente & Netherlands & 23 & 2.12 & 356 & 3.30 & 8 \\
\hline 6. & Eindhoven University of Technology & Netherlands & 21 & 1.94 & 751 & 6.96 & 9 \\
\hline $7-8$. & University of Sussex & United Kingdom & 18 & 1.66 & 1094 & 10.14 & 10 \\
\hline $7-8$ & University of Exeter & United Kingdom & 18 & 1.66 & 951 & 8.81 & 11 \\
\hline $9-10$. & Vrije University Amsterdam & Netherlands & 17 & 1.57 & 272 & 2.52 & 5 \\
\hline $9-10$. & Maastricht University & Netherlands & 17 & 1.57 & 213 & 1.97 & 6 \\
\hline
\end{tabular}

Source: Own study based on data retrieved from the Scopus database (accessed 27 May 2018).

\subsection{Journal Profiling}

Within the sample, there are 10 source titles that issued to 10 or more publications. The threshold of 5 and more publications is achieved by 28 source titles. Table 5 shows the topmost productive journals in responsible and sustainable innovations area.

Table 5. Top most productive source titles in research on responsible and sustainable innovations.

\begin{tabular}{|c|c|c|c|c|c|c|}
\hline \multirow{2}{*}{ No. } & \multirow{2}{*}{ Journal } & \multicolumn{2}{|c|}{ Publications } & \multicolumn{3}{|c|}{ Citations } \\
\hline & & $\mathbf{N}$ & $\%$ & $\mathbf{N}$ & $\%$ & $\mathbf{h}$ \\
\hline 1. & Journal of Cleaner Production & 64 & 5.91 & 1143 & 10.59 & 15 \\
\hline 2. & Journal of Responsible Innovation & 59 & 5.45 & 410 & 3.80 & 11 \\
\hline 3. & Sustainability Switzerland & 17 & 1.57 & 63 & 0.58 & 4 \\
\hline 4. & Science and Engineering Ethics & 15 & 1.39 & 156 & 1.45 & 7 \\
\hline $5-7$. & $\begin{array}{l}\text { International Journal of Innovation } \\
\text { and Sustainable Development }\end{array}$ & 14 & 1.29 & 55 & 0.51 & 4 \\
\hline $5-7$. & $\begin{array}{l}\text { Responsible Innovation 2: Concepts, } \\
\text { Approaches and Applications }\end{array}$ & 14 & 1.29 & 111 & 1.03 & 5 \\
\hline $5-7$. & $\begin{array}{l}\text { Responsible Innovation: Managing } \\
\text { the Responsible Emergence of } \\
\text { Science and Innovation in Society }\end{array}$ & 14 & 1.29 & 463 & 4.29 & 12 \\
\hline
\end{tabular}

Source: Own study based on data retrieved from the Scopus database (accessed 27 May 2018).

The most prolific and highly recognized source title in the field is the Journal of Cleaner Production, which published 64 articles receiving in total 1143 citations. The second place is occupied by the Journal of Responsible Innovation (59 articles cited 410 times). Other source titles differ significantly from the two leading ones in terms of the number of publications. It is worth noting that Responsible Innovation: Managing the Responsible Emergence of Science and Innovation in Society published only 14 articles, however, the number of their citations is the second in the series (cited 463 times). Noteworthy are also Science and Engineering Ethics (15 articles) cited 156 times and Responsible Innovation 2: Concepts, Approaches and Applications (14 articles) cited 111 times.

\subsection{Authors Profiling}

Only three authors contributed with more than 10 papers on responsible and sustainable innovations, while 25 researchers produced five publications or more. Topmost productive authors are listed in Table 6. 
Table 6. Topmost productive authors in research on responsible and sustainable innovations.

\begin{tabular}{|c|c|c|c|c|c|c|c|c|}
\hline \multirow{2}{*}{ No. } & \multirow{2}{*}{ Author } & \multirow{2}{*}{ Institution } & \multirow{2}{*}{ Country } & \multicolumn{2}{|c|}{ Publications } & \multicolumn{3}{|c|}{ Citations } \\
\hline & & & & $\mathbf{N}$ & $\%$ & $\mathbf{N}$ & $\%$ & $\mathbf{h}$ \\
\hline 1. & Blok V. & $\begin{array}{l}\text { Wageningen University and } \\
\text { Research Center }\end{array}$ & Netherlands & 15 & 1.39 & 164 & 1.52 & 7 \\
\hline $2-3$. & Fisher E. & Arizona State University & United States & 14 & 1.29 & 277 & 2.57 & 7 \\
\hline $2-3$. & Owen R. & University of Bristol & United Kingdom & 14 & 1.29 & 993 & 9.20 & 10 \\
\hline $4-5$. & Macnaghten P. & $\begin{array}{c}\text { Wageningen University and } \\
\text { Research Center }\end{array}$ & Netherlands & 9 & 0.83 & 771 & 7.15 & 6 \\
\hline $4-5$. & Özdemir V. & $\begin{array}{l}\text { Mary Ann Liebert, Inc.OMICS: } \\
\text { A Journal of Integrative Biology }\end{array}$ & United States & 9 & 0.83 & 73 & 0.68 & 6 \\
\hline $6-8$. & Guston D.H. & Arizona State University & United States & 8 & 0.74 & 152 & 1.41 & 5 \\
\hline $6-8$. & Smith A. & University of Sussex & United Kingdom & 8 & 0.74 & 742 & 6.88 & 7 \\
\hline $6-8$. & Swierstra T. & Maastricht University & Netherlands & 8 & 0.74 & 51 & 0.47 & 4 \\
\hline $9-11$. & Flipse S.M. & Delft University of Technology & Netherlands & 7 & 0.65 & 43 & 0.40 & 4 \\
\hline 9-11. & Quist J. & Delft University of Technology & Netherlands & 7 & 0.65 & 230 & 2.13 & 4 \\
\hline 9-11. & Stilgoe J. & University College London & United Kingdom & 7 & 0.65 & 776 & 7.19 & 6 \\
\hline
\end{tabular}

Source: Own study based on data retrieved from the Scopus database (accessed 27 May 2018).

In terms of the number of published articles, the most prolific author is V. Blok from Wageningen University and Research Center (15 articles), then E. Fisher from Arizona State University (14 articles) and R. Owen from the University of Bristol (14 articles). All of the aforesaid authors in their works discuss the framework for the responsible innovation concept. In his papers, V. Blok is mainly focused on providing the framework for responsible research and innovation, with particular stress on the challenges, insights, and perspectives of this concept. Among his scientific interests one can find the issues related to socio-ethical factors of innovations and their impact on society as well as the environment. R. Fisher from Arizona State University studies policy of science and technology, including the multi-level governance of new emerging technologies. In line with other leading researchers of responsible innovations, in his papers Fisher provides a conceptual understanding of changing relationships between science and society. He focuses on public policy demands for and practitioner responses to interdisciplinary collaborations between science and the humanities in order to enhance societal responsiveness. Also, R. Owen concentrates on the concept of responsible innovations. He highlights the necessity to include ethics issues into the governance of innovations and new technologies, as well as the need to engage society while managing innovation processes to enhance the ability of innovators to take responsibility for the future of this society. R. Owen is the most cited author (993 times). The second in terms of the citations number is J. Stilgoe from University College London, who published seven articles, cited 776 times. Co-working with R. Owen and P. Macnaghten, J. Stilgoe also explains the idea and complexity of the responsible research and innovation concept. P. Macnaghten from Wageningen University and Research Center, who is the next in order with the number of published articles (9), cited 771 times, deals with the issues related to the governance of science and technology and societal engagement. Noteworthy is also A. Smith from the University of Sussex, who published eight articles, cited 742 times. In his papers, Smith, similar to other most productive authors identified in Table 6, considers the politics and governance of innovation for sustainability. His research is of interdisciplinary character and draws upon theories and methodologies from sociology, political science, innovation studies, and science and technology studies. In Smith's scientific considerations one can find a particular field of interest regarding grassroots innovation for sustainability. The researcher seeks to understand the processes by which groups in civil society create and support innovations that seek to transform dominant social, economic and technological systems.

The most productive institution in the field i.e., the Delft University of Technology is represented by S. M. Flipse (cited 43 times) and J. Quist (cited 230 times), who published seven papers per person. Flipse's works focus mainly on interaction design for responsible innovation management. In his papers, Flipse stresses that four dimensions of responsible innovations (anticipation, reflection, 
deliberation, and responsiveness) require communication and collaboration of several market players. He concentrates on exploring how scientists and engineers can collaborate with other actors, in a functional way, thereby also functionally shaping responsible innovation practices. Also, J. Quist discusses the sustainable innovation concept. His works refer to the issues of business models for sustainable innovation, stakeholder inclusion and providing a methodological framework as well as participatory tools for this issue.

Having identified the key contributors among nations, institutions, source titles and authors, subject area profiling is the next step to map the research field. Its aim is to discover and portray the diversity and the multidimensionality of studies related to the issues of responsible and sustainable innovations.

\section{Subject Area Profiling}

The research output related to responsible and sustainable innovations is distributed over 26 subject areas. The highest number of publications is indexed in such areas as: Business, Management and Accounting (491), Engineering (279), Social Sciences (270), Environmental Science (206), Energy (144), Decision Sciences (137), Computer Science (129), Economics, Econometrics and Finance (108). All remaining areas include: Arts and Humanities (84), Medicine (75), Biochemistry, Genetics and Molecular Biology (46), Agricultural and Biological Sciences (38), Chemistry (38), Materials Science (36), Psychology (26), Chemical Engineering (23), Nursing (21), Earth and Planetary Sciences (14), Physics and Astronomy (14), Pharmacology, Toxicology and Pharmaceutics (10), Immunology and Microbiology (6), Multidisciplinary (6), Neuroscience (3), Veterinary (2), Health Professions (1). In order to thoroughly explore diversity and multidimensionality of research related to the issues of responsible and sustainable innovations research output in leading areas will be studied through the lens of key journals and authors, and core references. These leading areas under the study include Business, Management and Accounting, Engineering, Social Sciences, and Environmental Science.

\subsection{Journal—Subject Area Profiling}

Identifying top source titles in each of the leading subject areas is the first step of the subject area profiling. In Table 7, we present the topmost productive journals distributed by a subject area.

Table 7. Topmost productive journals by subject area.

\begin{tabular}{ll}
\hline Subject Area & Journals \\
\hline & Journal of Cleaner Production (63) \\
Business, Management and & Journal of Responsible Innovation (59) \\
Accounting (491) & Science and Engineering Ethics (15) \\
& International Journal of Innovation and Sustainable Development (14) \\
& Responsible Innovation 2: Concepts, Approaches and Applications (14) \\
\hline & Journal of Cleaner Production (63) \\
& Responsible Innovation 1: Innovative Solutions for Global Issues (9) \\
& International Journal of Sustainable Engineering (7) \\
& ASEE Annual Conference and Exposition Proceedings (5) \\
& IEEE International Engineering Management Conference (5) \\
& Sustainability Switzerland (17) \\
& Science and Engineering Ethics (15) \\
& Responsible Innovation 2: Concepts, Approaches and Applications (14) \\
Social Sciences (270) & Business Strategy and the Environment (11) \\
& Journal of Cleaner Production (63) \\
& Sustainability Switzerland (17) \\
& Business Strategy and the Environment (11) \\
\hline & Energy Policy (8) \\
\hline
\end{tabular}

Source: Own study based on data retrieved from the Scopus database (accessed 27 May 2018). 
Journal of Cleaner Production is the most universal and top-ranked journal in terms of the number of publications in the following three areas: Business, Management and Accounting, Engineering, and Environmental Science. Journal of Responsible Innovation is the second leading source title as regards the number of publications. All the publications (59) included in this journal relate to the subject area of Business, Management and Accounting only. Two other source titles, i.e., Science and Engineering Ethics and Responsible Innovation 2: Concepts, Approaches and Applications, bridge the areas of Business, Management and Accounting, and Social Sciences. Social Sciences and Environmental Science have two journals linking these two areas, i.e., Sustainability Switzerland (3rd position in the ranking of topmost productive titles) and Business Strategy and the Environment. All other source titles are specific to relevant areas. Engineering is found to be less interrelated with other subject areas.

\subsection{Journal—Subject Area Profiling}

Table 8 shows the most prolific authors identified in each of the leading subject areas in the field.

Table 8. Topmost productive authors by subject area.

\begin{tabular}{cc}
\hline Subject Area & Authors \\
\hline Business, Management and & Blok V. (12), Fisher E. (9), Owen R. (6), Swierstra T. (6), Flipse S.M. \\
Accounting (491) & (5), Guston D.H. (5), Huisingh D. (5), Macnaghten P. (5), Quist J. (5) \\
Engineering (279) & Huisingh D. (5), Quist J. (5), Lockton D. (4), Silvester S. (4), Som C. (4) \\
Social Sciences (270) & Blok V. (5), Fisher E. (5), Flipse S.M. (5) \\
Environmental Science (206) & Blok V. (6), Huisingh D. (5), Quist J. (5) \\
\hline
\end{tabular}

Source: Own study based on data retrieved from the Scopus database (accessed 27 May 2018).

In each of these areas, one can come across top-ranked authors conducting research on responsible and sustainable innovations. Many of the most prolific authors categorized in the area of Business, Management, and Accounting are found to contribute to other subject areas, too. V. Blok is the most prolific author in three areas, i.e., Business, Management and Accounting, Social Sciences, and Environmental Science. Other authors sharing their research between Business, Management and Accounting, and Social Sciences are E. Fisher and S.M. Flipse. The works by D. Huising and J. Quist bridge the area of Business, Management and Accounting with Engineering and Environmental Science. Summing up, a relatively high level of homogeneity is observed as regards the distribution of top authors through leading subject areas in research on responsible and sustainable innovations.

\subsection{Core References-Subject Area Profiling}

Core references analysis regards those works that have received the highest number of citations. Such references in relation to identified subject areas have been presented in Table 9. As shown in Table 9, we have distinguished four subject areas: Business, Management, and Accounting (BusMan\&Acc), Engineering (Eng), Social Sciences (SocSci), and Environmental Science (EnvSci).

The analysis of core references related to the identified subject areas allows to state that the work of Boons and Lüdeke-Freund [2] is shared among three areas: Business, Management and Accounting, Engineering, Social Sciences, and Environmental Science. In their paper, Boons and Lüdeke-Freund [2] consider how the issues of business models and sustainable innovations interrelate. They explore these links by proposing a set of normative requirements for a business model to contribute to market sustainable innovations as well as pointing out some barriers in marketing sustainable innovations. We assume that due to the fact that the authors take into account technological, organizational, and also social innovations, their paper is often cited in the three above mentioned subject areas. The conducted analysis of core references studied by subject areas shows that there are five works shared by two areas. The most cited of such papers is the work of Smith et al. [30]. It is shared by the areas of Business, Management and Accounting, and Engineering. Smith et al. [30] provide a review paper regarding a multi-level perspective on socio-technical transitions within innovation studies. On the 
other hand, the paper by Johnson et al. [31] is often cited both in the literature of Business, Management, and Accounting as well as Social Sciences. This results from the fact that in their work Johnson et al. [31] propose a planning model for sustaining innovations within an organization, community, and the state level. Thus, they highly focus on the social aspects of their research.

Table 9. Core references by a subject area.

\begin{tabular}{|c|c|c|c|c|c|}
\hline \multirow{2}{*}{ Article } & \multirow{2}{*}{ Citations } & \multicolumn{4}{|c|}{ Subject Areas } \\
\hline & & BusMan\&Acc & Eng & SocSci & EnvSci \\
\hline Schot and Geels [29] & 465 & $X$ & & & \\
\hline Smith et al. [30] & 452 & $x$ & $x$ & & \\
\hline Stilgoe et al. [14] & 325 & $x$ & & & \\
\hline Boons and Lüdeke-Freund [2] & 310 & $x$ & $x$ & & $x$ \\
\hline Johnson et al. [31] & 202 & $x$ & & $x$ & \\
\hline Stirling [32] & 300 & & $x$ & & \\
\hline Boons et al. [33] & 179 & & $x$ & & $x$ \\
\hline Nill and Kemp [34] & 176 & & $x$ & & \\
\hline Owen et al. [35] & 254 & & & $x$ & $x$ \\
\hline Bos-Brouwers [36] & 164 & & & $X$ & $x$ \\
\hline Larson [37] & 123 & & & $X$ & \\
\hline Ozaki [38] & 117 & & & $x$ & \\
\hline Ozaki and Sevastyanova [39] & 149 & & & & $x$ \\
\hline
\end{tabular}

Source: Own study based on data retrieved from the Scopus database (accessed 27 May 2018).

Moreover, as identified and shown in Table 9, Engineering and Environmental Science share the work of Boons et al. [33], who study the idea and nature of sustainable innovation and offer a conceptual framework for searching the link between sustainable business models, innovation, and competitiveness. In their paper, the authors provide an overview of innovation definitions and categories with a focus on ecological sustainability. Thus, it is not surprising that the paper is often cited in the field of Engineering and Environmental Science. The authors highlight also that the attributes of sustainable innovations are systemness and radicalness. Taking this perspective, Engineering seems to be the area interested in such an approach.

Finally, we have found two papers that are shared by Social Sciences and Environmental Science. There are works by Owen et al. [35] and Bos-Brouwers [36]. Owen et al. [35] provide a brief historical overview of the responsible (research and) innovation concept and concentrate on its four dimensions. Particularly, they stress the inclusive participation of different actors that allows in embedding research and innovation goals and potential impacts into societal and environmental values. They strongly focus on the fact that innovations should be generated for society and with society. On the other hand, Bos-Brouwers paper [36], also shared by Social Sciences and Environmental Science, points out that sustainable innovations result in positive social and environmental impacts. Presenting the research outcomes from a sample of small and medium enterprises, he argues that many sustainable innovations are directed into improvements of technological processes in the field of eco-efficiency, as well as to lower the cost of production. Thus, one can find here both environmental and social aspects of innovations.

Among the most often cited papers that belong only to one subject area, a paper of Stilgoe et al. [14] is worth noticing (325 citations). This work is assigned to the Business, Management and Accounting subject area. The authors of the paper develop a framework for the responsible (research and) innovation concept, highlighting the unpredictability of innovations that are inherently linked into its collective nature. The authors stress the complexity of the responsible (research and) innovation concept by explaining its dimensions in detail and indicating the techniques and approaches to make them alive. They also stress that the conception of responsibility should be built on the understanding that science and technology are socially as well as politically constituted. 
The procedure of research profiling is completed with topic profiling aimed at searching for predominant themes in the field by analyzing keywords from the perspective of authors, journals, subject areas, and core references.

\section{Topic Profiling}

\subsection{General Topic Profiling and Author-Topic Profiling}

Topic profiling is based on the keywords used by the authors in their papers and informs about the most important research patterns and points of view of the authors. Table 10 shows the main keywords used by authors.

First and foremost, the most popular keywords collected in Table 10 relate directly to the issues associated with responsible and sustainable innovations. The leading keywords here are: 'innovation', 'sustainable development', 'sustainable innovation', 'sustainability', and 'responsible innovation'. Other keywords show the relationships between responsible and sustainable innovations with people (human, humans), research, ethics, and technology. Some interesting tendencies may be also observed while studying the research interests of leading authors. For instance, Owen $[15,40]$ focuses his research on the issues related to innovations, responsible innovations, and research. Piccinno et al. [41] deal with sustainable development and sustainable innovations and Flipse et al. [42] are oriented to human and technological dimensions.

Table 10. Top 10 most often cited keywords.

\begin{tabular}{ll}
\hline Keywords & Authors \\
\hline Innovation (281) & $\begin{array}{l}\text { Owen R. (4), Smith A. (4), Edgeman R. (3), Eskilden J. (3), Kern F. (3), } \\
\text { Raven F. (3), Riel A. (3), Verhees B. (3), Wiek A. (3), Xiang G. (3) }\end{array}$ \\
\hline Sustainable development (231) & $\begin{array}{l}\text { Hischier R. (4), Huisingh D. (4), Piccinno F. (4), Seeger S. (4), } \\
\text { Smith A. (4), Som C. (4) }\end{array}$ \\
\hline Sustainable innovation (158) & Som C. (5), Hischier R. (4), Piccinno F. (4), Quist J. (4), Seeger S. (4), \\
\hline Sustainability (143) & $\begin{array}{l}\text { Foley R.W. (4), Bossink B.A.G. (3), Edgeman R. (3), Eskilden J. (3), } \\
\text { Huisingh D. (3), Wiek A. (3) }\end{array}$ \\
\hline Responsible innovation (129) & $\begin{array}{l}\text { Blok V. (6), Owen R. (5), Fisher E. (5), Macnaghten P. (5), Flipse S.M. (4), } \\
\text { Foley R.W. (4), Stilgoe J. (4), Wiek A. (4), Özdemir V. (4) }\end{array}$ \\
\hline Human (73) & $\begin{array}{l}\text { Özdemir V. (4), Osseweijer P. (5), Dove E.S. (4), Flipse S.M. (4), } \\
\text { Llerena A. (4), Shrivastava S. (4), Warnich L. (4) }\end{array}$ \\
\hline Humans (52) & $\begin{array}{l}\text { Osseweijer P. (4), Bredenoord A.L. (3), Flipse S.M. (3), } \\
\text { van der Sanden M.C.A. (3), Özdemir V. (3) }\end{array}$ \\
\hline Research (40) & Owen R. (3), Macnaghten P. (2), Stilgoe J. (2) \\
\hline Ethics (39) & $\begin{array}{l}\text { Bredenoord A.L. (3), Flipse S.M. (3), Osseweijer P. (3), } \\
\text { van der Sanden M.C.A. (3) }\end{array}$ \\
\hline Technology (39) & $\begin{array}{l}\text { Flipse S.M. (2), Kirna A.H. (2), Osseweijer P. (2), van Berkel R. (2), } \\
\text { van der Sanden M.C.A. (3) }\end{array}$ \\
\hline
\end{tabular}

Source: Own study based on data retrieved from Scopus database (accessed 27 May 2018).

\subsection{Source Title-Topic Profiling}

The topmost prolific source titles are focused on some particular topics. Table 11 shows the most often cited keywords by source title.

The papers published by the Journal of Cleaner Production are mainly focused on sustainable development, sustainable innovations, and innovations. Other topics studied in the journal are related to life-cycle and its assessment, product design and production engineering, and environmental impact. However, sustainability is a general 'umbrella' for all these topics. The leading topics in the Journal of Responsible Innovation are responsible innovation, responsible research, and general responsibility. 
More specific topics are focused on technology assessment, synthetic biology, governance, and public engagement. Both the aforementioned source titles combine the issues of technology in specific sectors with the ideas of responsibility and sustainability. Other journals contributing to the field with a smaller number of papers show similar tendencies. The most often studied topics in Sustainability Switzerland are innovation, sustainability, sustainable innovation, responsible research and innovation, and corporate social responsibility. In Science and Engineering Ethics, ethics is the leading keyword that is linked with responsible innovation, social innovation, ethics research and human (humans). International Journal of Innovation and Sustainable Development studies are focused on sustainable innovations, eco-innovations, environmental innovations, open innovations, and sustainable development. Responsible Innovation 2: Concepts, Approaches and Applications are centered on responsible innovation and responsibility. Additional research areas are connected with justice, stakeholders, and engagement. Finally, Responsible Innovation: Managing the Responsible Emergence of Science and Innovation in Society is focused mostly on responsible innovation. In general, it can be observed that the source titles under the study are centered on very similar research areas.

Table 11. Topmost often cited keywords by a source title.

\begin{tabular}{ll}
\hline Journal/ Source Title & Keywords \\
\hline Journal of Cleaner Production (64) & $\begin{array}{l}\text { sustainable development (46), sustainable innovation (28), } \\
\text { innovation (11), life-cycle (10), life cycle assessment (10), } \\
\text { sustainability (10), societies and institutions (9), product design (8), } \\
\text { environment impact (7), production engineering (7), sustainable } \\
\text { business (7) }\end{array}$ \\
\hline Journal of Responsible Innovation (59) & $\begin{array}{l}\text { responsible innovation (28), technology assessment (10), synthetic } \\
\text { biology (5), governance (4), innovation (4), responsibility (4), } \\
\text { responsible research and innovation (4), public engagement (3), } \\
\text { sustainability (3) }\end{array}$ \\
\hline Sustainability Switzerland (17) & $\begin{array}{l}\text { innovation (15), sustainability (9), sustainable innovation (6), } \\
\text { corporate social responsibility (5), responsible research and } \\
\text { innovation (5), sustainable development (4), entrepreneur (3), } \\
\text { organizational framework (3), RRI (3), responsible innovation (3) }\end{array}$ \\
\hline Science and Engineering Ethics (15) & $\begin{array}{l}\text { ethics (11), responsible innovation (10), human (9), humans (9), } \\
\text { science (7), social responsibility (6), technology (6) ethics research } \\
\text { (5), research ethics (5), social behavior (5) }\end{array}$ \\
\hline $\begin{array}{l}\text { International Journal of Innovation } \\
\text { and Sustainable Development (14) }\end{array}$ & $\begin{array}{l}\text { sustainable innovation (7), innovation (4), eco-innovation (2), } \\
\text { environmental innovation (2), open innovation (2) social systems } \\
\text { theory (2), sustainable development (2) }\end{array}$ \\
\hline $\begin{array}{l}\text { Responsible Innovation 2: Concepts, } \\
\text { Approaches and Applications (14) }\end{array}$ & $\begin{array}{l}\text { responsible innovation (6), justice (2), responsibility (2), } \\
\text { stakeholder engagement (2) }\end{array}$ \\
\hline Respers
\end{tabular}

Responsible Innovation: Managing the

Responsible Emergence of Science and responsible innovation (7)

Innovation in Society (14)

Source: Own study based on data retrieved from the Scopus database (accessed 27 May 2018).

\subsection{Subject Area-Topic Profiling}

Table 12 presents the most often cited keywords that have been used in the analyzed literature categorized by a subject area.

Generally, all the subject areas share their interest in such themes as innovation, sustainable development, sustainable innovation, responsible innovation, and sustainability. However, the analysis of data collected in Table 12 shows some aspects of research typical of relevant subject areas. For Business, Management and Accounting it is about technology, societies and institutions, planning and managing in the industrial context. Engineering is also oriented to product design, life cycle management, 
competition, and environmental impact. Social Sciences balance the focus on humanistic and technological aspects. Life cycle management, climate changes, and environmental impact are the issues characteristic of the research categorized within the subject area of Environmental Science.

Table 12. Topmost often cited keywords by a subject area.

\begin{tabular}{|c|c|}
\hline Subject Area & Keywords \\
\hline $\begin{array}{l}\text { Business, Management and } \\
\text { Accounting (491) }\end{array}$ & $\begin{array}{l}\text { innovation (125), sustainable development (114), sustainable innovation } \\
\text { (87), responsible innovation (74), sustainability (64), technology (21), } \\
\text { competition (20), societies and institutions (18), industry (16), industrial } \\
\text { management (15), planning (15), research (15) }\end{array}$ \\
\hline Engineering (279) & $\begin{array}{l}\text { sustainable development (119), innovation (73), sustainable innovation } \\
\text { (65), sustainability (27), product design (25), societies and institutions } \\
\text { (22), life cycle (18), competition (17), design (15), } \\
\text { environmental impact (15) }\end{array}$ \\
\hline Social Sciences (270) & $\begin{array}{l}\text { innovation (90), sustainability (60), sustainable development (47), } \\
\text { responsible innovation (44), sustainable innovation (34), ethics (21), } \\
\text { human (15), humans (15), responsible research and innovation (13), } \\
\text { technology (11) }\end{array}$ \\
\hline Environmental Science (206) & $\begin{array}{l}\text { sustainable development (84), innovation (78), sustainability (58), } \\
\text { sustainable innovation (52), environmental impact (14), life cycle } \\
\text { assessment (14), life cycle (13), Europe (13), societies and institutions (11), } \\
\text { climate change (10), decision making (10), responsible innovation (10) }\end{array}$ \\
\hline
\end{tabular}

Source: Own study based on data retrieved from the Scopus database (accessed 27 May 2018).

\subsection{Core References-Topic Profiling}

As already said, core references analysis regards those works that have received the highest number of citations. Such references in relation to identified topics are presented in Table 9. As shown in Table 13, we identified five such topics: innovation, sustainable development, sustainable innovation, sustainability, and responsible innovation.

Table 13. Top 5 most often cited core references by topic.

\begin{tabular}{ll}
\hline Keywords & Core References \\
\hline Innovation (281) & $\begin{array}{l}\text { Schot and Geels [29], Stilgoe et al. [14], Owen et al. [35], } \\
\text { Johnson et al. [31], Boons et al. [33] }\end{array}$ \\
\hline Sustainable development (231) & $\begin{array}{l}\text { Smith et al. [30], Boons and Lüdeke-Freund [2], Boons et al. [33], } \\
\text { Nill and Kemp [34], Bos-Brouwers [36] }\end{array}$ \\
\hline Sustainable innovation (158) & $\begin{array}{l}\text { Smith et al. [30], Boons and Lüdeke-Freund [2], Boons et al. [33], } \\
\text { Ozaki [38], Leach et al. [43] }\end{array}$ \\
\hline Sustainability (143) & $\begin{array}{l}\text { Schot and Geels [29], Johnson et al. [31], Bos-Brouwers [36], Larson [37], } \\
\text { Hellström [44] }\end{array}$ \\
\hline Responsible innovation (129) & $\begin{array}{l}\text { Stilgoe et al. [14], Owen et al. [15], Guston [45], Owen and Goldberg } \\
\text { [40], Hellström [46] }\end{array}$ \\
\hline
\end{tabular}

Source: Own study based on data retrieved from the Scopus database (accessed 27 May 2018).

The findings presented in Table 13 prove that several particular topics share some works. The papers shared by the three topics are done by Boons et al. [33] and Bos-Brouwers [36]. Also, there are several papers shared by two topics. These are Schot and Geels [29], Stilgoe et al. [14], and Johnson et al. [31]. The other core references identified in Table 13 have been assigned just to one topic.

Thus, in regard to the issue of innovation, already described works of Stilgoe et al. [14] as well as Owen et al. [35] provide the framework for the responsible (research and) innovation concept, 
pointing out the contemporary context in which innovations occur nowadays. Also mentioned before Boons et al. [33] present the idea of sustainable innovation linking it with the issue of a business model. Moreover, Johnson et al. [31], recalled before, discuss the definition of sustainability as well as present a prevention-focused sustainability-planning model for sustaining innovations highlighting key factors regarding sustainable innovations and the problems of dealing with them. As said before, the authors discuss these issues in relation to the organization, community and state level. On the other hand, Schot and Geels [29] suggest that sustainable innovations might be facilitated by creating technological niches. Thus, they follow the problem of strategic niche management, presenting how concepts and ideas have evolved over time.

Among the most often cited papers addressing the topic of sustainable innovation, Smith et al. [30] contribute by introducing a framework of multi-level perspective on sustainability transitions related to innovations, particularly stressing further research areas. Boons et al. [33] explain the idea and the nature of sustainable innovations. Furthermore, Boons and Lüdeke-Freund [2] contribute to the field by confronting the topic of sustainable innovation with the business model perspective. In their paper, the aforesaid authors provide a review of the literature on the interrelations between business models and sustainable innovations. Among the papers concentrating on sustainable innovation, there are some authors highlighting the issues of the environment as well as other global challenges of the 21st century. Thus, the problems of Sustainable Development Goals related to climate change, resource depletion, food production problems and poverty alleviation, aging societies, etc., are the topics of the paper by Leach et al. [43]. They argue that accomplishing these goals requires a new approach to innovations that involves different actors and processes within an inclusive, multi-scale innovation policy. Ozaki [38] deals with environmental innovations, focusing mostly on green electricity. She analyses the problem from consumers' point of view by posing a question concerning factors motivating consumers to adopt and pay for sustainable innovations.

Among the most often cited core references identified in relation to the topic of sustainable development, again Smith et al. [30], Boons et al. [33], as well as Boons and Lüdeke-Freund [2], have been found. Additionally, Bos-Brouwers [36] who was already mentioned before, explores the possibility of generating innovation oriented towards sustainable development. An interesting problem is discussed by Nill and Kemp [34] who explore the evolutionary approaches for sustainable innovation policies. They propose a framework integrating the strategic niche management approach, transition management approach and time strategies approach to contribute to sustainable development, particularly focusing on their strengths and specific problems.

Among the publications regarding the topic of sustainability, the most often cited again are the papers of Schot and Geels [29], Johnson et al. [31], Bos-Brouwers [36]. In addition, Larson [37] presents an interesting example of environmental and sustainability considerations integration into business strategy. Hellström [44] in his work studies environmentally sustainable innovation from the perspective of innovation theories in order to establish successful ways forward.

As far as the topic of responsible innovation is concerned, the most often cited works belong to already mentioned Stilgoe et al. [14] and Owen et al. [15]. Considering the issues of responsible innovation, some authors point out the problem of anticipatory governance necessary to promote the emergence of responsible innovations. These aspects are highlighted by Owen and Goldberg [40] who focus on the necessity of anticipating and understanding the wide potential impacts and associated with new products and technologies. The aforementioned authors stress the need for continuous reflectivity and anticipation to support the decisions shaping the trajectory of innovation in time. Also Guston [45] discusses the issue of anticipatory governance based on reflection of scientists, policymakers and other public players who share responsibility within the innovation process. In a similar vein, Hellström [46] raises the problem of the risk associated with systemic innovation. He explores how new complex technological systems generate risk or negative synergies on several levels of society. 


\section{Discussion}

\subsection{Overlapping Concepts}

The analysis of literature on responsible innovation proves that there are different approaches to explain and define it. Several authors describe this new concept as Responsible Research and Innovation, responsible innovation, or sustainable innovation. We start our study by following von Schomberg [47] who provides the commonly used definition of Responsible Research and Innovation (RRI). According to aforesaid author, RRI is "a transparent, interactive process by which societal actors and innovators become mutually responsive to each other with a view to the (ethical) acceptability, sustainability and societal desirability of the innovation process and its marketable products (in order to allow embedding of scientific and technological advances in our society)" [47] (p. 9). Responsible Research and Innovation has been also defined in the European Union documents which say that RRI is "an on-going process of aligning research and innovation to the values, needs and expectations of society" [48] (p. 1).

In line with the abovementioned, a central point of the RRI idea is that it embeds responsibility at very early stages of research and innovation by emphasizing research integrity, several institutional environments, and dynamics with a strong bearing on the societal impact of business $[49,50]$. The concept points out that research and innovation can be responsible in many ways: environmentally, ethically, as well as socially or politically. Thus, it highlights the necessity of collaboration of various market players responsible for research and innovation, such as research founders, policymakers, business entities, etc., to promote a transition to mutual responsibility [51]. Dove and Özdemir [52] highlight that the RRI concept is multidimensional and complex, and thus it needs including natural sciences, social sciences, and humanities as well as political forces that influence the structure of knowledge-based innovations into collaboration. Moreover, the RRI approach emphasizes the cooperation of different groups of stakeholders in order to come up with sustainable solutions focused on ethical acceptability, sustainability and societal desirability of the innovation process and its marketable outcomes that influence society $[9,15,53]$. Summing up, RRI focuses on incorporating responsibility into the DNA of contemporary companies and requires that the products or outcomes of innovation meet deeply held moral values [54,55].

Following von Schomberg's explanation of RRI, Owen, Stilgoe, and Macnaghten, provide their definition of the term 'responsible innovation'. They highlight that responsible innovation refers to taking care of the future through collective stewardship of science and innovation in the present [15]. On the other hand, Noorman, Swierstra, and Zandbergen emphasize that responsible innovation is a normative conception of technology development, which hopes to improve upon prevailing practices [56]. While considering the analyzed concept, several authors highlight that stakeholder engagement is the key characteristic of responsible innovation [56-61]. Stakeholders together with the members of the public are involved upstream in the innovation process and encouraged to deliberate on the features and uncertainties related to the innovation [14,18]. Stakeholder and public members' inclusion are perceived as a strategy to become mutually responsive to each other and anticipate research and innovation results in the context of serious social and environmental challenges (climate change, resource depletion, poverty alleviation, aging societies, etc.) for which they share responsibility [57]. This collective responsibility enables to control and direct innovation into ethically acceptable, societally desirable, and sustainable direction [9,56]. Blok and Lemmens [58] stress that, in the concept of responsible innovation, responsibility is perceived as the extension to 'regular innovation' pointing out stakeholder involvement particularly regarding ethical and societal aspects of innovation. They highlight that due to this extension, the innovation process is better enabled to balance economic, socio-cultural as well as environmental interests.

Burget, Bardone, and Pedaste [62], who analyzed the matter of responsible innovation based on the review of 235 RRI-related articles, notice that policymakers and scientists define and conceptualize responsible innovation in different ways. Having reviewed several conceptual approaches, the aforesaid 
authors propose the following definition: "Responsible innovation is essentially an attempt to govern research and innovation in order to include all the stakeholders and the public in the early stages of research and development. The inclusion of different actors and the public is, in turn, meant to increase the possibilities to anticipate and discern how research and innovation can or may benefit society as well as prevent any negative consequences from happening" [62] (p. 15).

In the relevant literature, the idea of responsible innovation is explained also in terms of four dimensions, pointing out that to innovate responsively requires to be anticipatory, reflective, inclusively deliberate, and responsive [14,63]. In this context, responsible innovations, considered as an outcome of smart planning and actions, are based on motivations related to the company's influence on the workplace, society and the environment. Anticipation means describing and analyzing the intended but also potentially unintended impacts related to economic, social or environmental aspects that may arise in future related to the innovation that is to be developed [14]. This requires that innovators understand the dynamics shaping innovation [62]. Thus, anticipation refers to asking questions: 'What if ... ?' and 'What else might it do?'. This refers to another responsible innovations' dimension that is reflectivity. Being reflective requires analyzing motivations and potential impacts of innovations, taking into account both what is known but also what is uncertain and unknown. It also refers to being aware of the limits of knowledge and the fact that one's reality might not be universally held $[14,64]$. Inclusion and deliberation are focused in all works on responsible innovation, as they are related to other dimensions [62]. Inclusion and deliberation refer to upstream engagement of stakeholders and public members in the discussions aimed at analyzing social, political, environmental, as well as ethical implications that the development of the innovation could bring $[14,65]$. The fourth dimension of responsible innovation is responsiveness. It is about having the capacity to change the shape of innovation or its direction responding to values of stakeholders and the wider public [18]. Here, it seems necessary to say that care and responsiveness are two dimensions of prospective responsibility [20,66-69]. They allow market players to reflect on the purposes and outcomes of science and innovation. Responsiveness is a key dimension allowing several options to be kept open $[32,70]$. The company's responsiveness means being adaptive, responding to the views and perspectives of the public and stakeholders. In other words, it refers to being deliberative. This means that responsible innovations are the outcome of continuous dialogue with various groups of stakeholders which shows the features of the organizational learning process-oriented to dynamic adjustment to changing needs.

An extensive literature review on responsible and sustainable innovation allows to state that sustainable innovation overlaps conceptually with responsible innovation [71,72]. Sustainable innovations, like responsible innovations, are intended to respond to contemporary societal and environmental challenges. Furthermore, Lubberink et al. as well as Adams et al. highlight that both responsible and sustainable innovations are focused on sustainability as a desirable outcome of innovation [71,72]. Adams et al. also state that sustainable innovations require the collaboration of a complex network of stakeholders. This enables engagement in dialogue necessary to acquire the knowledge needed to generate responsive solutions [71]. Moreover, both responsible and sustainable innovations take into account economic, environmental as well as social dimension while considering innovation outcomes [18].

An interesting point of view is presented by Dyck and Silvestre who distinguish between 'sustainable innovation 1.0' and 'sustainable innovation 2.0'. According to aforesaid authors, the term 'sustainable innovation $1.0^{\prime}$ ' refers to innovations that are aimed at both reducing an organization's negative socioecological externalities and enhancing their financial interests. On the contrary, as 'sustainable innovation 2.0' they describe innovations that are driven by the social and ecological returns they will generate. In other words, Dyck and Silvestre highlight that the ultimate goal of 'sustainable innovation 2.0' is to improve overall social and ecological well-being. This type of innovation enables organizations to enhance positive socio-ecological externalities while remaining financially viable but not needing to maximize financial returns [73]. 
Taking the corresponding perspective in analyzing the idea of sustainable innovation, Boons, Montalvo, Quist, and Wagner propose a general explanation stating that sustainable innovation is an innovation that improves sustainability performance in terms of ecological, economic, and social criteria. They propose a definition of sustainable innovation saying it is "a process where sustainability considerations (environmental, social, and financial) are integrated into company systems from idea generation through research and development (R\&D) to commercialization. This applies to products, services, and technologies, as well as to new business and organizational models" [33] (p. 4). Taking such a point of view, sustainable innovation will have different meanings and characteristics in different contexts. Additionally, the aforementioned researchers argue that due to the fact that responsible innovations go beyond regular product and process innovations and are future-oriented, they are characterized by systemness and radicalness.

In the similar vein, Bos-Brouwers, and Calik and Bardudeen claim that as 'sustainable' one may call an innovation in which the improvement of products, services, technological or organizational processes commercialized or internally implemented, not only brings in an improved economic performance but also enhances environmental and social performance. Thus, both in the short and long term, sustainable innovations have the capacity to generate positive social and environmental impacts $[36,74,75]$. In addition, Tello and Yoon particularly emphasize the care of resource deployment, pointing out that sustainable innovation can be defined as new products, processes, services, and technologies which contribute to the development and well-being of human needs and institutions by respecting the worlds' natural resources and regenerative capacity [76].

An interesting approach is proposed by Hargadon [21]. According to him, sustainable innovation means two things. First, following the definition of Bruntland Commission, he argues that the term refers to generating, developing and launching new products and processes which "meet the needs of the present without compromising the ability of future generations to meet their own needs" [77]. In other words, the term 'sustainable innovation' refers to the new products and processes that consume fewer environmental resources, foster people's health as well as are affordable for both consumers and producers. Secondly, the aforesaid author claims that sustainable innovation also means building an organization that is capable of sustaining the pace of innovation over several years (ten or more). He proposes his second explanation with the comment that a single innovation will neither support a company nor drive fundamental change within the industry [21]. In other words, the implementation of sustainable innovations expresses the care of enterprises for the future manifested in making business decisions based on anticipation and reflection made today.

However, while considering the matter of sustainable innovation, Zeng et al. stress that it is difficult to achieve within a single organization [78]. The aforementioned authors highlight the necessity of creating sustainable innovation ecosystems formed by continuous interactions among organizations, policies, society and the environment. In their considerations, they refer to the open innovation concept [79,80], pointing out that nowadays most industries adopt an open approach to innovating [78]. This enables identifying future customer needs, as well as scanning for disruptions through foresight networks [78,81].

Finally, some authors indicate sustainable innovations as a concept consisting of several approaches to sustainability-related (sustainability-oriented) innovations, like green innovations, eco-innovations, environmental innovations, grass-root innovations, socially-responsible innovations, etc. [28,71,82-87]. In the literature the term environmental innovation (short: eco-innovation) is defined very broadly and regards all measures of relevant actors (firms, politicians, unions, associations, churches, private households) that develop new ideas, behavior, products, and processes, apply or introduce them and that contribute to a reduction of environmental burdens or to ecologically specified sustainability targets $[82,88]$. On the other hand, the term 'grassroots innovations' is used to describe networks of activists and organizations generating novel bottom-up solutions for sustainable development. These are the solutions that respond to the local situation and the interests and values of the communities involved. A highlighted by Seyfang and Smith [83], in contrast to mainstream 
business greening, grassroots initiatives operate in civil society arenas and involve committed activists experimenting with social innovations as well as using greener technologies. Social innovations (socially-responsible innovations) seem to be the most multi-dimensional category of abovesaid. It is characterized by several approaches in the literature. Despite different approaches, the common point in defining this category refers to the fact that social (socially-responsible) innovations play a significant role in meeting social needs and solve several social problems both in organizations and society [89-92].

\subsection{Research Patterns}

Having discussed central ideas of the overlapping concepts of responsible research and innovations, responsible innovations or sustainable innovations, the next step is to provide the critical assessment of the reasons for the scholarly research to have developed along with certain patterns. In regard to research patterns in the field, our particular interest is focused on: (1) the dominant position in the field occupied by the Netherlands, Dutch universities and researchers, (2) the leading position of Journal of Cleaner Production and Journal of Responsible Innovation among most productive source titles in the field, (3) multidimensionality of research perspectives in the field.

The dominant position in the field occupied by the Netherlands, Dutch universities and researchers imposes the question why is it so? Of course, there are several reasons for such a situation. However, the first reason for focusing on innovations (also responsible innovations) both in research and practice seems to be the fact that the Netherlands is a country with low land and flat geography, known as the safest delta in the world, with $26 \%$ of the country area and almost half of its population are located below the sea level. Moreover, despite its size, it is one of the most densely populated nations in the world. All circumstances that make the Netherlands a low-lying, flood-prone country caused the necessity for the Dutch government as well as the citizens to be innovative in protecting the land against flooding and to secure freshwater supplies [93].

Secondly, as pointed out by Hofstede [94], the Netherlands is a Feminine society which means that the dominant values in society are caring for others and quality of life. In Feminine countries, it is important to keep the life/work balance and to make sure that all are included. Conflicts are resolved by compromise and negotiation and the Dutch are known for their long discussions until consensus has been reached [95]. Moreover, tough life conditions related to the country situated below the sea level forced people to work together in order to reclaim the land from the sea. In turn, nowadays the Netherlands is relatively unique in practicing a strong consensus-driven approach to decision making. As far as the field of responsible innovation is concerned, it has to be highlighted that in the Netherlands, there is a long tradition of negotiations: between public organizations, enterprises, trade unions, consumer pressure groups as well as NGOs [96]. Additionally, the Netherlands has an egalitarian society which results in thinking that everyone is equal and should be treated accordingly [97]. This virtue directly refers to the issue of stakeholders' engagement while anticipating innovations' impact on the society or environment. It also enables firms and citizens to better understand the main idea of responsible innovation concept.

Another explanation for the dominant position of Dutch researchers and universities in the field of responsible innovation regards the configuration of the Dutch research eco-system. A strong Dutch science base, world-class companies combined with government support policies result in an ecosystem with strong linkages between innovation partners. Dutch research eco-system fosters the development of innovations (and focuses on responsible innovations) as it involves different entities such as universities and research institutes, government policymakers, companies, civil society organizations, and financial institutions. The main cornerstones of Dutch innovation research ecosystem are: interconnections and networking between participants, sharing and creating of knowledge and technology, providing diversity in financial sources for partners in innovation, and boosting the business climate [98]. Thanks to having such a peculiar configuration of the innovation eco-system, Dutch enterprises are among the world's leading innovators with strong technological capabilities and performance [99]. The Netherlands' innovative top sectors are among the world's best. The country's top 
nine sectors include: horticulture and propagation materials, agri-food, water, life sciences and health, chemicals, high tech, energy, logistics, and creative industries [100]. All the abovementioned sectors are closely related to the concept of responsible innovations that focuses on providing new products and processes that generate profits and at the same time are socially and environmentally accepted.

Another reason for the dominant position in the field occupied by the Netherlands, Dutch universities and researchers, refers to the fact that the country has very strong universities as reflected in the number and quality of scientific publications. Most Dutch universities do very well in international rankings [99]. Thus, Dutch researches follow the new concepts and fields of knowledge developing in the world. The research on responsible innovation issues is so developed in the Netherlands also due to some special governmental funding for research in this area. The field of responsible innovation is of particular interest to The Netherlands Organization for Scientific Research, falling under the responsibility of the Ministry of Education, Culture and Science. The organization implements funding instruments for several fields, among them for responsible innovation domain. The Netherlands Organization for Scientific Research frequently opens new registration rounds for the research in the field of responsible innovation. In addition, the organization has a platform for responsible innovation to provide information, inspiration, and contacts for researchers, companies, government bodies, and societal organizations. The platform focuses on providing researchers with outcomes and experiences from the research programs, that already have been financed. In turn, all participants interested in exploring the field are able to get knowledge about responsible innovations in various areas including life sciences and healthcare, energy transition, agriculture, and food. Additionally, the platform provides guidelines and tools for companies, government bodies, and other stakeholders to implement insights from projects in responsible innovation processes, models for the design process of innovations, and new business models [101].

The leading position of the Journal of Cleaner Production and Journal of Responsible Innovation among the most productive source titles in the field is the next pattern to be noticed while discussing the development of research on the concepts of responsible and sustainable innovations. What are the reasons for such achievements? In our opinion, the attention should be given to three following aspects: high quality and very good matching of the scopes of these source titles with the issues of responsible and sustainable innovations, openness for research perspectives from various subject areas, and networking with leading research institutions in the field.

The Journal of Cleaner Production is focused on the concept of cleaner production which "aims at preventing the production of waste while increasing efficiencies in the uses of energy, water, resources, and human capital" [102]. The scope of the Journal of Cleaner Production encompasses such aspects as sustainability, sustainable development, products, services or consumption which can be considered as the outputs of responsible innovation processes. The high quality of the journal is confirmed by the value of its impact factor (5.561) in the Journal Citation Report (JCR) 2017 by Clarivate Analytics and the Scimago Journal Rank (SJR) indicator as of 2017 (1.467). Since 2006, it has been listed in the first quartile (Q1) of source titles in all four subject areas categories where indexed i.e.,: Environmental Science, Engineering (Industrial and Manufacturing Engineering), Energy (Renewable Energy, Sustainability and the Environment), Business, Management and Accounting (Strategy and Management). Therefore, it seems to be obvious that the Journal of Cleaner Production belongs to priority choices of scholars searching for a quality source title to submit their papers. This strong position in various subject areas in the field is confirmed by our study of subject area/journal profiling (cf. Table 7).

Responsible innovation is per se the center of gravity for the Journal of Responsible Innovation, which is manifested in its source title. What is important the Journal of Responsible Innovation invites the studies applying various research perspectives and representing diverse subject areas. The scope of accepted papers ranges from humanities and legal studies through social sciences to science and engineering [103]. In consequence, direct reference to the issue of responsible innovation in conjunction with its multidimensionality predestine the journal to become one of the leading platforms for disseminating research findings in the field. However, what is interesting, in spite of the declared 
scope encompassing a wide range of subject areas, the scientific output published in the Journal of Responsible Innovation is mainly categorized within the Business, Management and Accounting subject area. The journal is not found among the most influential source titles of other leading subject areas in the field i.e., Engineering, Social Sciences or Environmental Science (cf. Table 7). The network of relations with key actors in the field is another aspect that may be considered among the strengths of the journal and explaining its competitive position. The Journal of Responsible Innovation is well-linked with leading research centers in the field. As officially announced on its website, the journal is supported by four following institutions: Arizona State University, the University of Exeter, Maastricht University, and Karlsruhe Institute of Technology (JRI, nd). Three of them are found to be among the most productive organizations in research on responsible and sustainable innovations (cf. Table 4).

Multidimensionality of research perspectives in the field is another feature of scientific production related to responsible and sustainable innovations. As found, the research output is distributed over 26 subject areas ranging from science through social sciences to humanities. The highest number of publications is indexed in such areas as Business, Management and Accounting, Engineering, Social Sciences, Environmental Science, Energy, Decision Sciences, Computer Science, Economics, Econometrics and Finance. Therefore, the question arises: why is the research output in the field distributed among so many subject areas? The concepts of responsible and sustainable innovations respond to up-to-date problems faced by governments, businesses, non-governmental organizations, and individuals. Due to their multidimensionality, the ideas of responsible innovations match to research questions considered as central in many subject areas. Generally, as pointed out in Section 6.3, all the leading subject areas in the field share their interest in such themes as innovation, sustainable development, sustainable innovation, responsible innovation, and sustainability. However, some specificity and particular interests of researchers cultivating in various subject areas may be noticed. For instance, in the areas Business, Management and Accounting it is about technology, societies and institutions, planning and managing in the industrial context. Engineering is also oriented to product design, life cycle management, competition, and environmental impact. Social Sciences balance the focus on humanistic and technological aspects. Life cycle management, climate changes, and environmental impact are the issues characteristic of the research categorized within the subject area of Environmental Science. Due to its inclusiveness, the research field encompasses the research conducted from the perspective of technology (e.g., in subject areas of Engineering and Computer Science), the environment (studies related to Environmental Science and Energy), humans and society (Social Sciences) or economy and business (subject areas related to Economics, Econometrics and Finance as well as Business, Management and Accounting). What are the consequences of this multidimensionality for conducting research?-which is the next issue to be discussed. Firstly, crossing the boundaries between subject areas is observed. In consequence, numerous publications are indexed as referring to more than one subject area. For instance, Business, Management and Accounting shares its research output with 16 other subject areas, including in particular: Engineering (119 publications), Decision Sciences (111), Social Sciences (94), Environmental Science (91), Economics, Econometrics and Finance (83), and Energy (82). Similar tendencies are noticed while analyzing other leading subject areas. Due to strong interrelatedness with other subject areas and a high number of publications, Business, Management and Accounting studies seem to have the potential to play an integrating role in the field. Secondly, diversity of research perspectives due to the extended multidimensionality may result in combining research methodologies typical of related subject areas leading to search for synergy in eclectic research approaches. Nevertheless, so far it is challenging to provide strong evidence to support such an observation, which requires further exploration.

\subsection{New Research Avenues}

Analyzing and discussing existing research patterns in the field is very important to fully understand the situation, its antecedents, and circumstances. However, to make the step forward and 
contribute to the development of the field, the identification of unexplored aspects or possible future avenues of research from the perspective of policy, practice, and theory are needed.

While indicating new directions for further research, first of all, it is necessary to point out that responsible research and innovation concept is highly predestinated for cross-disciplinary research and thinking beyond established boundaries. The problem of creating responsible innovations is very complex so it requires complex research-based dialogue between scholars from different disciplines to engage with management research. However, to produce positive outcomes, responsible innovations are to be embedded in the business context. Therefore, one of the new directions for further research in the field is searching for the business context of responsible innovations. The current discussion on responsible innovations is not capturing enough attention from the business community [104]. The concept of responsible innovations has been implemented mainly in the context of publicly funded research with little effort to adapt and operationalize it for the business context [12,104]. Further research requires to focus on drivers of responsible innovation and measures of the outcomes resulting from implementing the responsible innovation concept. In regard to responsible innovation drivers, it is interesting to investigate what are these drivers and under what conditions they will facilitate responsible innovation best. Also the issue regarding the way of measuring responsible innovation in business is of great importance. Van de Poel et al. highlight that the concept of Responsible Research and Innovation needs to be translated into business-relevant key performance indicators [49]. The authors provide methodological steps for developing such key performance indicators. However, the avenue for further research is searching for measuring the returns of responsible research and innovation in the business context. There is still a lack of the works providing such measures as well as the research-based on larger-scale quantitative empirical testing. Search for fact-based evidence in the business context seems to be of high significance for enhancing the managerial practice in firms. In our opinion quantitative research is essential for further development of the concept and its implementation in companies. Also, the commercial dynamics related to responsible innovations are poorly developed in the literature of the field [104]. Thus, this seems to be an interesting path for researchers to follow in the future.

Another issue regarding further research refers to the industry sector and local specific factors regarding implementing the concept of responsible research and innovation in the business context. Sector-specific differences so far have not been taken into account in the research on responsible innovation and in turn some sectors are underrepresented. The sectors most often mentioned in the works on responsible innovation are nanotechnology and ICT [12]. However, singular policy and technological solutions which appear optimal from the global perspective rarely prove viable or desirable in all industries and localities. The differences in sector specificity or different cultural and ecological settings require varied approaches [43]. The insights from other industries and sectors will contribute to developing a better conceptualization of responsible innovation and to distinguishing sector-specific characteristics of its application [12]. Furthermore, such variables as governance structure, company size, organizational culture, leadership or team dynamics require particular attention while conducting research on implementing the responsible innovation concept in the business context. Investigating how abovementioned aspects contribute to responsible innovation will add some new valued for theory of management, the practice of firms as well as policies.

Alternating avenue for further research regarding responsible research and innovation refers to the networked nature of the concept in the business context with a particular focus on value chain issues. Nowadays, there is a considerable agreement among researchers that most firms innovate in networks, cooperating with their supply chain partners. While taking such a perspective, further research should focus on responsibility of individual companies in creating responsible innovations. In our opinion, further research going beyond the implementation of responsible innovation just in individual companies would highly enrich the understanding of complexity and interrelations of firms within their value chains while focusing on responsibility in innovation contexts. This will be a contribution to the development of the theory of management. 
Also, the role of business in defining as well as enforcing governance mechanisms, that facilitate responsible innovation, with particular attention on the access and involvement of business in political processes seems to be an interesting direction for further research contributing in terms of policy and practice.

The next avenue for further research in the field refers to the distribution of both commercial and socio-economic benefits of responsible innovation. As there are conflicting interests between several actors related to the innovation process, it seems important to ask the question: who gains and who loses from particular policies and innovations? The significant issues here are the following: what sort of development and responsibility is being pursued, for whom and how what this implies, how such choices are made in relation to what values in a particular social and political context? Thus, monitoring the policy and the process of responsible innovation creation requires keeping the issues of benefits distribution at the center. The research focused on such aspects is of high significance for both policy and practice.

Also, examining the relationship between disruptive and emerging technologies (e.g., robotics, artificial intelligence, synthetic biology, etc.) and society seems to be a promising avenue for further research. An interesting question here regards the challenges for a society that are emerging from the development of new areas of science. While following this research path it seems important to concentrate on the ways of accounting for and managing the risks posed by emerging technologies and building trust towards emerging technologies in the community. Furthermore, while considering the macro-level, it seems interesting to investigate the implications of recent societal developments, such as emerging nationalism or fundamentalism, for responsible innovation. The research could try to provide the answers to the question: how and why can these developments foster or hinder responsible innovation? Abovesaid areas of research also could contribute in terms of theory and policy.

Taking the consumer perspective on responsible innovation also seems to be an interesting direction for further research. The inhibitors to the responsible innovation concept adoption in the industry, such as strong differences among multiple stakeholders, incentives for not sharing information with competitors, limited human abilities to predict all innovation consequences [58], cause responsible innovation to be a costly process. From the firms' perspective, it can be justified only if responsible innovation creates valued attributes that consumers are willing to pay for [105]. Thus, it seems necessary to conduct research aimed at recognizing demands from citizens for responsible innovation. In our opinion, for responsible innovation in order to be financially feasible, further research is required to understand how credence attributes can be marketed to consumers' chains that increase returns to producers and processors.

\section{Conclusions}

Analysis of research productivity and the number of citations received by publications included in the sample confirm the growing interest of the academia in research on responsible and sustainable innovations. Making an attempt to map the key players in the research field, contributions made by nations, research institutions, journals, and authors have been studied. The representatives of European, North American, South American and Asian nations are found among the most productive countries. In regards to quantity of the research output, the leaders in the field are the Netherlands, the United Kingdom, and the United States. Taking into account quality of the research, Germany should be added to the aforementioned countries. The ranking of the top 10 most productive research institutions in the field is dominated by the Netherlands. Dutch universities and research centers occupy the top three positions in regard to the number of publications. The Delft University of Technology is the unquestionable leader. However, the highest number of citations is received by two British institutions i.e., the University of Sussex and the University of Exeter. The most prolific and highly recognized source title in the field is the Journal of Cleaner Production, which published 64 articles, receiving a total of 1143 citations. 
The most prolific authors in the field are V. Blok from Wageningen University and Research Center (Netherlands), E. Fisher from Arizona State University (United States) and R. Owen from the University of Bristol (United Kingdom). When it comes to the number of received citations, the leaders are R. Owen, J. Stilgoe from University College London (United Kingdom), P. Macnaghten from Wageningen University and Research Center (Netherlands), and A. Smith from the University of Sussex (United Kingdom).

Subject area profiling has aimed at exploring diversity and the multidimensionality of research related to the issues of responsible and sustainable innovations. The study has been focused on key journals and authors, and core references representing the four following leading subject areas in the field: Business, Management and Accounting, Engineering, Social Sciences, and Environmental Science. The Journal of Cleaner Production is recognized to be the most universal and top-ranked journal in terms of the number of publications in the following three areas: Business, Management and Accounting, Engineering, and Environmental Science. Moreover, there are titles shared by Business, Management and Accounting, and Social Sciences (i.e., Science and Engineering Ethics and Responsible Innovation 2: Concepts, Approaches and Applications) as well as Social Sciences and Environmental Science (Sustainability Switzerland, Business Strategy and the Environment). In regard to source titles, Engineering is found to be less interrelated with other subject areas. A relatively high level of homogeneity is observed as regards the distribution of the top authors through leading subject areas in research on responsible and sustainable innovations. V. Blok is recognized to be the most prolific author in three areas, i.e., Business, Management and Accounting, Social Sciences, and Environmental Science. Similarly, the profiling for core references shows a lot of links between the subject areas in the field. Analyzing the top five core references in each of the leading areas, we identified one paper [2] shared among three areas and five other works shared by at least two subject areas. Summing up, subject area profiling shows a relatively high level of interrelatedness among the four leading areas under the study i.e., Business, Management and Accounting, Engineering, Social Sciences, and Environmental Science in regard to authors, source titles and core references.

Finally, the topic profiling has been completed with the aim of searching for predominant themes in the field by analyzing keywords from the perspective of authors, journals, subject areas, and core references. Analyzing the most often cited keywords two interesting thematic streams may be observed in the field. First of all, the leading keywords such as: 'innovation', 'sustainable development', 'sustainable innovation', 'sustainability' and 'responsible innovation' concentrate the attention on the core aspects of responsible and sustainable innovations. Secondly, the keywords indicate the relationships of the concept with people (human, humans), research, ethics, and technology. Topic-subject areas profiling shows that generally all the subject areas share their interest in such themes as innovation, sustainable development, sustainable innovation, responsible innovation, and sustainability. However, some aspects of research typical of relevant subject areas may be found e.g., product design and life cycle management in Engineering, humanistic and technological issues in Social Sciences, or life cycle management and environmental impact in the case of Environment Science. Finally, we have analyzed the core references related to the following leading topics: innovation, sustainable development, sustainable innovation, sustainability, and responsible innovation. The analysis indicates that several particular topics share some works. For instance, the publications by Boons et al. [33] and Bos-Brouwers [36] are shared by three topics, while Schot and Geels [29], Stilgoe et al. [14], and Johnson et al. [31] contribute with their research to two of leading themes. Similarly to the study of the research field from the perspective of subject areas, topic profiling indicates links and bridges between topics analyzed through the prism of authors, source titles, subject areas, and core references.

Discussing the findings of research profiling, overlapping approaches in the literature on responsible innovation are worth noticing. Several authors describe this new concept as responsible research and innovation, responsible innovation, or sustainable innovation. Moreover, some other concepts combining the ideas of innovations and corporate social responsibility and focusing 
on particular aspects may be observed, e.g., environmental innovations, grassroots innovations, and social innovations.

In regard to research patterns in the field, the discussion has been focused on the reasons for scholarly research to have developed along certain lines. Making an attempt to explain the dominant position in the field occupied by the Netherlands, Dutch universities and researchers, geographical and cultural aspects are to be mentioned first. Being a flood-prone country caused the necessity for the Dutch government as well as citizens to be innovative in protecting the land against flooding and to secure freshwater supplies. Moreover, the Netherlands is a Feminine society which means that the dominant values in society are caring for others and quality of life. Next, it should be noticed that the Dutch research eco-system fosters the development of innovations (and focus on responsible innovations) as it involves different entities such as: universities and research institutes, government policymakers, companies, civil society organizations, and financial institutions. What is also of paramount importance is the fact that the country has very strong universities as reflected in the number and quality of scientific publications. Considering the leading position of the Journal of Cleaner Production and Journal of Responsible Innovation among the most productive source titles in the field, we assume it has been achieved due to: high quality and very good matching of the scopes of these source titles with the issues of responsible and sustainable innovations, openness for research perspectives from various subject areas, and networking with leading research institutions in the field. Multidimensionality of perspectives is a high feature of research in the field. The concepts of responsible and sustainable innovations respond to up-to-date problems faced by governments, businesses, non-governmental organizations, and individuals. Due to their multidimensionality, the ideas of responsible innovations match to research questions considered as central in many subject areas.

Finally, the discussion has concentrated attention on the identification of unexplored aspects or possible future avenues of research. Among them, the three following lines are worth noticing: (1) searching for the business context of responsible innovations, (2) exploring networked nature of the concept in the business context with particular focus on value chain issues, and (3) examining the relationship between disruptive and emerging technologies (e.g. robotics, artificial intelligence, synthetic biology etc.) and society.

The study makes a contribution to the body of knowledge on responsible and sustainable innovations through mapping the research field, discussing existing research patterns and their antecedents, and identifying new research avenues. Firstly, the paper identifies key contributors (nations, research institutions, journals, and authors) providing the answer to the question about the constituents of the research community [23]. Secondly, the paper explores the interdisciplinarity of research in the field analyzing outputs in leading subject areas i.e., Business, Management and Accounting, Engineering, Social Sciences, and Environmental Science. Thirdly, it contributes to topic profiling, analyzing most often cited keywords, in order to explore thematic boundaries of the field. Both, the second and third parts of the study make an attempt to identify the most central research issues in the field [23].

The paper is of theoretical character, so it contributes mainly to the development of the body of knowledge in management sciences. Nevertheless, some implications it has for business practice are worth considering, too. As observed by Lis [106], bibliometric studies aimed at mapping research fields in management sciences may be useful for managers in four ways. Firstly, the identification of leading research institutions and the most prolific and highly recognized authors enable the companies interested in cooperation with academia to find out the relevant partners. Secondly, recognition of the most productive source titles (journals) and core references receiving the attention of the research community provides an indication for managers searching for valuable sources of information and knowledge. Thirdly, discovery of leading and emerging study topics may focus the attention of business practitioners on key and 'hot' issues, they should deal with. Fourthly, highlighting some research topics discussed in literature may catalyze identification of real-life managerial problems and submitting them as proposals for further studies. In regard to the issue of responsible and sustainable innovation 
explored in our paper, two other aspects should be highlighted. The paper discusses an interesting case of the Dutch research ecosystem, finding it among the reasons standing behind the strong position of the Netherlands in the research field focused on responsible innovations. Development of this ecosystem, combining the efforts of universities and research institutes, government policymakers, companies, civil society organizations, and financial institutions, could be considered as a good practice recommended for implementation in other areas in order to strengthen cooperation between academia and its business environment. Finally, the paper reveals the industries which have been relatively well studied in regard to developing and implementing responsible innovations as well as those which still require more investigation embedded in their particular contexts.

Concluding, the limitations of the study and recommendations for further research should be discussed. Firstly, limitations related to some level of subjectivity associated with the research profiling methodology need to be pointed out. Therefore in the future, it is suggested to supplement the mapping of the research field with other bibliometric methods and techniques. Secondly, there are limitations caused by the research sampling process. Scopus is considered to be one of the largest and most prestigious bibliometric databases. However, it covers only a part of the research output. What is more, Scopus is very much biased to publications in English, while neglecting those issued in other languages, which results in a natural gap while sampling for the bibliometric study. In consequence, replication of the study with the use of other bibliometric databases is worth considering. Thirdly, bibliometric studies, as literature quantitative studies, provide a general, but not a very thorough, analysis of the situation in the research field. That is why they should be supplemented with qualitative literature surveys. Finally, due to the very dynamic development of the research field, we find a static, one-time analysis to be insufficient. Therefore, the replication of the study in the future is recommended to observe changing trends and shifts in the research field over time.

Author Contributions: A.L. initiated the project and conceptualized the paper, designed methodology as well as retrieved and prepared data for analysis. All the authors (A.L., A.S. and M.C.) were responsible for data analysis. A.S. and A.L. contributed to introduction, discussion, and conclusion sections as well as editing the manuscript.

Funding: This research received no external funding.

Acknowledgments: The paper was supported with statutory research funding of the Faculty of Economic Sciences and Management, Nicolaus Copernicus University in Torun, Poland and WSB University in Torun, Poland.

Conflicts of Interest: The authors declare no conflict of interest.

\section{References}

1. Bouglet, J.; Joffre, O.; Simon, E. How to reconcile business with sustainable development: An innovation approach. Soc. Bus. Rev. 2012, 50, 307-336. [CrossRef]

2. Boons, F.; Lüdeke-Freund, F. Business models for sustainable innovation: State-of-the-art and steps towards a research agenda. J. Clean. Prod. 2013, 45, 9-19. [CrossRef]

3. Starik, M.; Kanashiro, P. Toward a theory of sustainability management. Organ. Environ. 2013, 26, 7-30. [CrossRef]

4. Montiel, I.; Delgado-Ceballos, J. Defining and measuring corporate sustainability. Organ. Environ. 2014, 27, 113-139. [CrossRef]

5. Carroll, A.B. Corporate social responsibility. Organ. Dyn. 2015, 44, 87-96. [CrossRef]

6. Kolk, A. The social responsibility of international business: From ethics and the environment to CSR and sustainable development. J. World Bus. 2016, 51, 23-34. [CrossRef]

7. Barnett, M.L. The business case for corporate social responsibility: A critique and an indirect path forward. Bus. Soc. 2019, 58, 167-190. [CrossRef]

8. Grunwald, A. Responsible innovation: Bringing together technology assessment, applied ethics and STS research. Enterp. Work Innov. Stud. 2011, 7, 9-13.

9. von Schomberg, R. Prospects for technology assessment in a framework of responsible research and innovation. In Technikfolgen Abschatzen Lehren; Dusseldorp, M., Beecroft, R., Eds.; VS Verlag fur Socialwissenschaften: Wiesbaden, Germany, 2012; pp. 39-61. 
10. Rip, A. The past and future of RRI. Life Sci. Soc. Policy 2014, 10, 1-15. [CrossRef]

11. Zwart, H.; Landeweerd, L.; van Rooij, A. Adapt or perish? Assessing the recent shift in the European research funding arena from 'ELSA' to 'RRI'. Life Sci. Soc. Policy 2014, 10, 1-19. [CrossRef]

12. Blok, V.; Martinuzzi, A.; Brem, A.; Stahl, B.; Schonherr, N. Responsible research and innovation in industry-Challenges, insights and perspectives. Sustainability 2018, 10, 702. [CrossRef]

13. Griffy-Brown, C.; Earp, B.D.; Rosas, O. Technology and the good society. Technol. Soc. 2018, 52, 1-78. [CrossRef]

14. Stilgoe, J.; Owen, R.; Macnaghten, P. Developing a framework for responsible innovation. Res. Policy 2013, 42, 1568-1580. [CrossRef]

15. Owen, R.; Stilgoe, J.; Macnaghten, P.; Gorman, M.; Fisher, E.; Guston, D. A framework for responsible innovation. In Responsible Innovation. Managing the Responsible Emergence of Science and Innovation in Society; Owen, R., Bessant, J., Heintz, M., Eds.; Wiley: London, UK, 2013; pp. 27-50.

16. Macnaghten, P.; Owen, R.; Stilgoe, J.; Wynne, B.; Azevedo, A.; de Campos, A.; Chilvers, J.; Dagnino, R.; di Giulio, G.; Frow, E. Responsible innovation across borders: Tensions, paradoxes and possibilities. J. Respir. Innov. 2014, 1, 191-199. [CrossRef]

17. Ribeiro, B.E.; Smith, R.D.J.; Millar, K.A. A mobilising concept? Unpacking academic representations of responsible research and innovation. Sci. Eng. Ethics 2016, 23, 81-103. [CrossRef] [PubMed]

18. Lubberink, R.; Blok, V.; van Ophem, J.; Omta, O. Lessons from responsible innovations in the business context: A systematic literature review of responsible, social and sustainable innovation practices. Sustainability 2017, 9, 721. [CrossRef]

19. Groves, C. Future ethics: Risk, care and non-reciprocal responsibility. J. Glob. Ethics 2009, 5, 17-31. [CrossRef]

20. Adam, B.; Groves, C. Futures tended: Care and future-oriented responsibility. Bull. Sci. Technol. Soc. 2011, 31, 17-27. [CrossRef]

21. Hargadon, A. Sustainable Innovation: Build Your Company's Capacity to Change the World; Stanford University Press: Stanford, CA, USA, 2015.

22. Osareh, F. Bibliometrics, citation analysis and co-citation analysis: A review of literature I. Libri 1996, 46, 149-158. [CrossRef]

23. Porter, A.L.; Kongthon, A.; Lu, J.C. Research profiling: Improving the literature review. Scientometrics 2002, 53, 351-370. [CrossRef]

24. Martinez, H.; Jaime, A.; Camacho, J. Relative absorptive capacity: A research profiling. Scientometrics 2012, 92, 657-674. [CrossRef]

25. Choi, D.G.; Lee, H.; Sung, T. Research profiling for 'standardization and innovation'. Scientometrics 2011, 88, 259-278. [CrossRef]

26. Lis, A. General research profiling for the concept of a 'learning organization'. In Business and Non-profit Organizations Facing Increased Competition and Growing Customers' Demands; Nalepka, A., Ujwary-Gil, A., Eds.; Wyższa Szkoła Biznesu-National Louis University: Nowy Sacz, Poland, 2017; pp. 75-92.

27. Lis, A.; Czerniachowicz, B.; Wieczorek-Szymańska, A. Leadership and corporate social responsibility: Research topic profiling. In Business and Non-profit Organizations Facing Increased Competition and Growing Customers' Demands; Nalepka, A., Ujwary-Gil, A., Eds.; Wyższa Szkoła Biznesu-National Louis University: Nowy Sacz, Poland, 2017; pp. 59-74.

28. Lis, A.; Sudolska, A. W poszukiwaniu typologii innowacji społecznie odpowiedzialnych: Mapowanie pola badawczego. Stud. I Prace Wydz. Nauk Ekon. I Zarz. Uniw. Szczec. 2018, 52, 115-126. [CrossRef]

29. Schot, J.; Geels, F.W. Strategic niche management and sustainable innovation journey: Theory, findings, research agenda, and policy. Technol. Anal. Strateg. Manag. 2008, 20, 537-554. [CrossRef]

30. Smith, A.; Voß, J.P.; Grin, J. Innovation studies and sustainability transitions: The allure of the multi-level perspective and its challenges. Res. Policy 2010, 39, 435-448. [CrossRef]

31. Johnson, K.; Hays, C.; Center, H.; Daley, C. Building capacity and sustainable prevention innovations: A sustainability planning model. Eval. Program Plan. 2004, 27, 135-149. [CrossRef]

32. Stirling, A. A general framework for analysing diversity in science, technology and society. J. R. Soc. Interface 2007, 4, 707-719. [CrossRef]

33. Boons, F.; Montalvo, C.; Quist, J.; Wagner, M. Sustainable innovation, business models and economic performance: An overview. J. Clean. Prod. 2013, 45, 1-8. [CrossRef] 
34. Nill, J.; Kemp, R. Evolutionary approaches for sustainable innovation policies: From niche to paradigm? Res. Policy 2009, 38, 668-680. [CrossRef]

35. Owen, R.; Macnaghten, P.; Stilgoe, J. Responsible research and innovation: From science in society to science for society, with society. Sci. Publ. Policy 2012, 39, 751-760. [CrossRef]

36. Bos-Brouwers, H.E.J. Corporate sustainability and innovation in SMEs: Evidence of themes and activities in practice. Bus. Strategy Environ. 2010, 19, 417-435. [CrossRef]

37. Larson, A.L. Sustainable innovation through an entrepreneurship lens. Bus. Strategy Environ. 2000, 9, 304-317. [CrossRef]

38. Ozaki, R. Adopting sustainable innovation: What makes consumers sign up to green electricity? Bus. Strategy Environ. 2011, 20, 1-17. [CrossRef]

39. Ozaki, R.; Sevastyanova, K. Going hybrid: An analysis of consumer purchase motivations. Energy Policy 2011, 39, 2217-2227. [CrossRef]

40. Owen, R.; Goldberg, N. Responsible innovation: A pilot study with the U.K. Engineering and Physical Sciences Research Council. Risk Anal. 2010, 30, 1699-1707. [CrossRef]

41. Piccinno, F.; Hischier, R.; Seeger, S.; Som, C. From laboratory to industrial scale: A scale-up framework for chemical processes in life cycle assessment studies. J. Clean. Prod. 2016, 125, 1085-1097. [CrossRef]

42. Flipse, S.M.; de Winde, J.H.; Özdemir, P.; van der Sanden, M.C.A. The wicked problem of Socially Responsible Innovation. EMBO Rep. 2014, 15, 464. [CrossRef]

43. Leach, M.; Rockström, J.; Raskin, P.; Scoones, I.; Stirling, A.C.; Smith, A.; Thompson, J.; Millstone, E.; Ely, A.; Arond, E.; et al. Transforming innovation for sustainability. Ecol. Soc. 2012, 17. [CrossRef]

44. Hellström, T. Dimensions of environmentally sustainable innovation: The structure of eco-innovation concepts. Sustain. Dev. 2007, 15, 148-159. [CrossRef]

45. Guston, D.H. Understanding 'anticipatory governance'. Soc. Stud. Sci. 2014, 44, 218-242. [CrossRef]

46. Hellström, T. Systemic innovation and risk: Technology assessment and the challenge of responsible innovation. Technol. Soc. 2003, 25, 369-384. [CrossRef]

47. von Schomberg, R. Introduction: Towards responsible and innovation in the information and communication technologies and security technologies field. In Towards Responsible Research and Innovation in the Information and Communication Technologies and Security Technologies Field; von Schomberg, R., Ed.; Publications Office of the European Union: Luxemburg, 2011; pp. 7-15.

48. European Union. Rome Declaration on Responsible Research and Innovation in Europe; European Union: Brussels, Belgium, 2014. Available online: https://ec.europa.eu/research/swafs/pdf/rome_declaration_RRI_final_21_ November.pdf (accessed on 1 August 2018).

49. van de Poel, I.; Asveld, L.; Flipse, S.; Klaassen, P.; Scholten, V.; Yaghmaei, E. Company strategies for responsible research and innovation (RRI): A conceptual model. Sustainability 2017, 9, 2045. [CrossRef]

50. Blok, V.; Scholten, V.; Lon, T.B. Responsible innovation in industry and the importance of customer orientation: Introduction to the special issue. Int. Food Agribus. Manag. Rev. 2018, 21, 455-462. [CrossRef]

51. Foxon, T.; Pearson, P. Overcoming barriers to innovation and diffusion of cleaner technologies: Some features of a sustainable innovation policy regime. J. Clean. Prod. 2008, 16, S148-S161. [CrossRef]

52. Dove, E.S.; Özdemir, V. The epiknowlegde of socially responsible innovation. EMBO Rep. 2014, 15, 462-463. [CrossRef]

53. Stahl, B.; Obach, M.; Yaghmaei, E.; Ikonen, V.; Chatfield, K.; Brem, A. The responsible research and innovation (RRI) maturity model: Linking theory and practice. Sustainability 2017, 9, 1036. [CrossRef]

54. Viesser, W. The Age of Responsibility: CSR 2.0; Wiley: New York, NY, USA, 2011.

55. Van den Hoven, J. Value sensitive design and responsible innovation. In Responsible Innovation. Managing the Responsible Emergence of Science and Innovation in Society; Owen, R., Bessant, J., Heintz, M., Eds.; Wiley: London, UK, 2013; pp. 75-84.

56. Noorman, M.; Swierstra, T.; Zandbergen, D. Questioning the normative core of RI: The challenges posed to stakeholder engagement in a corporate setting. In Responsible Innovation 3: A European Agenda? Asveld, L., van Dam-Mieras, R., Swierstra, T., Lavrijssen, S., Linse, K., van den Hoven, J., Eds.; Springer International Publishing: Cham, Germany, 2017; pp. 231-249.

57. von Schomberg, R. A vision of responsible research and innovation. In Responsible Innovation. Managing the Responsible Emergence of Science and Innovation in Society; Owen, R., Bessant, J., Heintz, M., Eds.; Wiley: London, UK, 2013; pp. 51-74. 
58. Blok, V.; Lemmens, P. The emerging concept of responsible innovation: Three reasons why it is questionable and calls for a radical transformation of the concept of innovation. In Responsible Innovation 2: Concepts, Approaches and Applications; Koops, B.J., Oosterlaken, I., van den Hoven, J., Romijn, H.A., Swierstra, T.E., Eds.; Springer: Dordrecht, The Netherland, 2015; pp. 19-35.

59. Koops, B.J. The concepts, approaches, and applications of responsible innovation: An introduction. In Responsible Innovation 2: Concepts, Approaches and Applications; Koops, B.J., Oosterlaken, I., van den Hoven, J., Romijn, H.A., Swierstra, T.E., Eds.; Springer: Dordrecht, The Netherland, 2015; pp. 1-15.

60. Maier, M.A.; Brem, A.; Kauke, M. Exploring the boundaries of corporate social responsibility and innovation: A conceptual framework of socio-political stakeholders and their integration into the innovation process. Int. J. Innov. Sustain. Dev. 2016, 10, 312-337. [CrossRef]

61. Vollero, A.; Palazzo, M.; Siano, A.; Elving, W.J.L. Avoiding the greenwashing trap: Between CSR communication and stakeholder engagement. Int. J. Innov. Sustain. Dev. 2016, 10, 120-140. [CrossRef]

62. Burget, M.; Bardone, E.; Pedaste, M. Definitions and conceptual dimensions of responsible research and innovation: A literature review. Sci. Eng. Ethics 2016, 23, 1-19. [CrossRef]

63. Swierstra, T. Economic, technological, and socio-epistemological drivers behind RRI. In Responsible Innovation 3: A European Agenda? Asveld, L., van Dam-Mieras, R., Swierstra, T., Lavrijssen, S., Linse, K., van den Hoven, J., Eds.; Springer International Publishing: Cham, Germany, 2017; pp. 9-20.

64. Lee, R.G.; Petts, J. Adaptive governance for responsible innovation. In Responsible Innovation. Managing the Responsible Emergence of Science and Innovation in Society; Owen, R., Bessant, J., Heintz, M., Eds.; Wiley: London, UK, 2013; pp. 143-164.

65. Wickson, F.; Carew, A.L. Quality criteria and indicators for responsible research and innovation: Learning from transdisciplinarity. J. Responsible Innov. 2014, 1, 254-273. [CrossRef]

66. Richardson, H.S. Institutionally divided moral responsibility. In Responsibility; Miller, E.F., Paul, J., Eds.; Cambridge University Press: Cambridge, UK, 1999; pp. 218-249.

67. Pellizzoni, L. Responsibility and environmental governance. Environ. Politcs 2004, 13, 541-565. [CrossRef]

68. Groves, C. Technological futures and non-reciprocal responsibility. Int. J. Humanit. 2006, 4, 57-61. [CrossRef]

69. Grinbaum, A.; Groves, C. What is 'responsible' about responsible innovation? Understanding the ethical issues. In Responsible Innovation. Managing the Responsible Emergence of Science and Innovation in Society; Owen, R., Bessant, J., Heintz, M., Eds.; Wiley: London, UK, 2013; pp. 119-142.

70. Stirling, A. "Opening up" and "closing down": Power, participation, and pluralism in the social appraisal of technology. Sci. Technol. Hum. Values 2007, 33, 262-294. [CrossRef]

71. Adams, R.; Jeanrenaud, S.; Bessant, J.; Denyer, D.; Overy, P. Sustainability-oriented innovation: A systematic review. Int. J. Manag. Rev. 2015, 18, 180-205. [CrossRef]

72. Lubberink, R.; Blok, V.; van Ophem, J.; Omta, O. A framework for responsible innovation in the business context: Lessons from responsible-, social- and sustainable innovation. In Responsible Innovation 3: A European Agenda? Asveld, L., van Dam-Mieras, R., Swierstra, T., Lavrijssen, S., Linse, K., van den Hoven, J., Eds.; Springer International Publishing: Cham, Germany, 2017; pp. 181-207.

73. Dyck, B.; Silvestre, B.S. Enhancing socio-ecological value creation through sustainable innovation 2.0: Moving away from maximizing financial value capture. J. Clean. Prod. 2018, 171, 1593-1604. [CrossRef]

74. Horbach, J. Indicator Systems for Sustainable Innovation, Sustainability and Innovation; Physica-Verlag Heidelberg: Heidelberg, Germany, 2005.

75. Calik, E.; Bardudeen, F. A measurement scale to evaluate sustainable innovation performance in manufacturing organizations. 13th Global Conference on Sustainable Manufacturing-Decoupling Growth from Resource Use. Procedia CIRP 2016, 40, 449-454. [CrossRef]

76. Tello, S.F.; Yoon, E. Examining drivers of sustainable innovation. Int. J. Bus. Strateg. 2008, 8, 164-169.

77. Great Britain and World Commission on Environment and Development. Our Common Future: A Perspective by the United Kingdom on the Report of the World Commission on Environment and Development; Department of the Environment: London, UK, 1988.

78. Zeng, D.; Hu, J.; Ouyang, T. Managing innovation paradox in the sustainable innovation ecosystem: A case study of ambidextrous capability in a focal firm. Sustainability 2017, 9, 2091. [CrossRef]

79. Chesbrough, H. Open Business Models: How to Thrive in the New Innovation Landscape; Harvard Business School Press: Boston, MA, USA, 2006. 
80. Chesbrough, H. Open innovation: A new paradigm for understanding industrial innovation. In Open Innovation. Researching a New Paradigm; Chesbrough, H., Vanhaverbeke, W., West, J., Eds.; Oxford University Press: Oxford, UK, 2008; pp. 1-12.

81. Calof, J.; Meissner, D.; Razheva, A. Overcoming open innovation challenges: A contribution from foresight and foresight networks. Technol. Anal. Strateg. Manag. 2018, 30, 718-733. [CrossRef]

82. Rennings, K. Redefining innovation-Eco-innovation research and the contribution from ecological economics. Ecol. Econ. 2000, 32, 319-332. [CrossRef]

83. Seyfang, G.; Smith, A. Grassroots innovations for sustainable development: Towards a new research and policy agenda. Environ. Politics 2007, 16, 584-603. [CrossRef]

84. Schiederig, T.; Tietze, F.; Herstatt, C. Green innovation in technology and innovation management-An exploratory literature review. $R$ D Manag. 2012, 42, 180-192. [CrossRef]

85. Flipse, S.M.; Van Der Sanden, M.C.A.; Radstake, M.; De Winde, J.H.; Osseweijer, P. The DNA of socially responsible innovation: Social and natural scientists need to establish mutual understanding and a common language to efficiently work together. EMBO Rep. 2014, 15, 134-137. [CrossRef] [PubMed]

86. Franceschini, S.; Faria, L.G.D.; Jurowetzki, R. Unveiling scientific communities about sustainability and innovation: A bibliometric journey around sustainable terms. J. Clean. Prod. 2016, 127, 72-83. [CrossRef]

87. Loya, M.I.M.; Rawani, A.M. Adoption factors for green brick innovation: An empirical study of consumers in India. Int. J. Innov. Sustain. Dev. 2017, 11, 23-36. [CrossRef]

88. Klemmer, P.; Lehr, U.; Lobbe, K. Environmental Innovation: Volume 3 of Publications from a Joint Project on Innovation Impacts of Environmental Policy Instruments; Synthesis Report of a Project Commissioned by the German Ministry of Research and Technology (BMBF); Analytica-Verlag: Berlin, Germany, 1999.

89. OECD. LEED Forum on Social Innovations. 2000. Available online: http://www.oecd.org/cfe/leed/ForumSocial-Innovations.htm (accessed on 15 July 2018).

90. Heiscala, R. Social innovations: Structural and power perspectives. In Social Innovations, Institutional Change and Economic Performance; Hamalainen, T.J., Heiskala, R., Eds.; Edward Elgar: Cheltenham, UK, 2007; pp. 52-79.

91. Mulgan, G. Social Silicon Valleys: A Manifesto for Social Innovations; The Young Foundation: London, UK, 2007.

92. Harris, M.; Albury, D. The Innovation Imperative; NESTA: London, UK, 2009.

93. Hisham, S. A Country Built by Innovation: The Netherlands. Geospatial World. Available online: https://www.geospatialworld.net/article/a-country-built-by-innovation-the-netherlands/ (accessed on 6 September 2018).

94. Hofstede, G. Culture's Consequences: Comparing Values, Behaviors, Institutions, and Organizations Across Nations; Sage: Thousand Oaks, CA, USA, 2001.

95. Hofstede Insights. Available online: https://www.hofstede-insights.com/country/the-netherlands/ (accessed on 3 September 2018).

96. Best Practices in The Netherlands. Available online: https://thegreentake.wordpress.com/tag/the-netherlands (accessed on 5 September 2018).

97. Hampden-Turner, C.; Trompenaars, A. The Seven Cultures of Capitalism: Value Systems for Creating Wealth in Britain, the United States, Germany, France, Japan, Sweden and The Netherlands; Doubleday Business: New York, NY, USA, 1995.

98. Building an Ecosystem to Foster Innovation. Available online: https://no.nl/en/about-tno/news/2017/5/ building-on-ecosystem-to-foster-innovation/ (accessed on 30 July 2018).

99. OECD Reviews on Innovation Policy: The Netherlands. Overall Assessment and Recommendations. Available online: www.oecd.org/sti/innovation/reviews (accessed on 5 September 2018).

100. Encouraging Innovation. Available online: www.government.nl/topics/enterprise-and-innovation/ encouraging-innovation (accessed on 3 September 2018).

101. The Dutch Research Council (NWO). Available online: https://www.nwo.nl/en (accessed on 1 September 2018).

102. JCLP (nd). Journal of Cleaner Production. Available online: https://www.journals.elsevier.com/journal-ofcleaner-production/ (accessed on 20 June 2018).

103. JRI (nd). Journal of Responsible Innovation: Aims and Scope. Available online: https://www.tandfonline. com/action/journalInformation?show=aimsScope\&journalCode=tjri20 (accessed on 20 June 2018). 
104. Silva, H.P.; Lehoux, P.; Miller, F.A.; Denis, J.L. Introducing responsible innovation in health: A policy-oriented framework. Health Res. Policy Syst. 2018, 16. [CrossRef]

105. Dalziel, P.; Saunders, C.; Tait, P.; Saunders, J.; Miller, S.; Guenther, M.; Rutherford, P.; Driver, T. Rewarding responsible innovation when consumers are distant from producers: Evidence from New Zealand. Int. Food Agribus. Manag. Rev. 2018, 21, 487-504. [CrossRef]

106. Lis, A. Managing organization development: Identifying research patterns and mapping the research field. In Contemporary Challenges in Cooperation and Coopetition in the Age of Industry 4.0; Zakrzewska-Bielawska, A., Staniec, I., Eds.; Springer: Cham, Switzerland, 2020; pp. 375-396.

(C) 2019 by the authors. Licensee MDPI, Basel, Switzerland. This article is an open access article distributed under the terms and conditions of the Creative Commons Attribution (CC BY) license (http://creativecommons.org/licenses/by/4.0/). 